\title{
Anti-Inflammatory Effects of Curcumin in the Inflammatory Diseases: Status, Limitations and Countermeasures
}

\author{
Ying Peng' \\ Mingyue Ao' \\ Baohua Dong' \\ Yunxiu Jiang' \\ Lingying $\mathrm{Yu}^{\prime}$ \\ Zhimin Chen' \\ Changjiang $\mathrm{Hu}^{1,2}$ \\ Runchun $\mathrm{Xu}^{\mathrm{l}}$
}

'State Key Laboratory of Southwestern Chinese Medicine Resources; Pharmacy College, Chengdu University of

Traditional Chinese Medicine, Chengdu, People's Republic of China; ${ }^{2} \mathrm{Neo}-\mathrm{Green}$ Pharmaceutical Co., Ltd., Chengdu, People's Republic of China
Correspondence: Zhimin Chen;

Changjiang $\mathrm{Hu}$

Email chenzhimin@cdutcm.edu.cn;

654460129@qq.com

\begin{abstract}
Curcumin is a natural compound with great potential for disease treatment. A large number of studies have proved that curcumin has a variety of biological activities, among which anti-inflammatory effect is a significant feature of it. Inflammation is a complex and pervasive physiological and pathological process. The physiological and pathological mechanisms of inflammatory bowel disease, psoriasis, atherosclerosis, COVID-19 and other research focus diseases are not clear yet, and they are considered to be related to inflammation. The anti-inflammatory effect of curcumin can effectively improve the symptoms of these diseases and is expected to be a candidate drug for the treatment of related diseases. This paper mainly reviews the anti-inflammatory effect of curcumin, the inflammatory pathological mechanism of related diseases, the regulatory effect of curcumin on these, and the latest research results on the improvement of curcumin pharmacokinetics. It is beneficial to the further study of curcumin and provides new ideas and insights for the development of curcumin anti-inflammatory preparations.
\end{abstract}

Keywords: anti-inflammatory, osteoarthritis, psoriasis, atherosclerotic, pharmacokinetics, prodrug

\section{Introduction}

Curcumin, chemically known as 1,7-bis(4-hydroxy-3-methoxyphenyl)-1, 6-heptadiene-3, 5-dione, has anti-inflammatory, anti-oxidant, anti-tumor and other biological activities. ${ }^{1}$ The anti-inflammatory properties of curcumin are considered to be the basis of its various biological activities and play an important role in the treatment of diseases. Curcumin is mainly derived from the root tuber of Curcuma aromatica Salisb and the rhizome of $C$. longa L. (Turmeric) of Zingiberaceae. They are traditional Chinese medicines that promote blood circulation and remove blood stasis, and have long been used in China to treat pain, inflammation and other diseases. Turmeric is a common spice in India and has been described in Ayurveda, as a treatment for inflammatory diseases. ${ }^{2}$ In western herbalism, turmeric is primarily used as an antiinflammatory agent. ${ }^{3}$ Curcumin and curcuminoids, the active components of turmeric, are found as effective therapies over the years. Curcumin, demethoxycurcumin and bisdemethoxycurcumin, these three compounds are called curcuminoids (Figure 1). In addition, curcumin-containing dietary supplements are extremely popular, and there are many anti-oxidant and anti-inflammatory curcumin dietary supplements on the market. $^{4,5}$ 
<smiles>COc1cc(/C=C/C(=O)CC(=O)/C=C/c2ccc(O)c(OC)c2)ccc1O</smiles><smiles>COc1cc(/C=C/C(=O)CC(=O)/C=C/c2ccc(O)cc2)ccc1O</smiles>

Demethoxycurcumin<smiles>O=C(/C=C/c1ccc(O)cc1)CC(=O)/C=C/c1ccc(O)cc1</smiles>

Bisdemethoxycurcumin

Figure I Chemical structure of curcuminoids (include curcumin, demethoxycurcumin, bisdemethoxycurcumin).

Inflammation is a complex physiological and pathological process. Inflammation is typically an adaptive response caused by harmful stimuli and conditions (such as infection and tissue damage) to keep the body homeostasis. Inflammation can be divided into acute inflammation and chronic inflammation. The acute inflammation lasts only a short time and is usually beneficial to the host. When inflammation persists for a long time, it becomes chronic and can contribute to a variety of chronic diseases, such as obesity, diabetes, arthritis, pancreatitis, cardiovascular, neurodegenerative, metabolic diseases, and some types of cancer. ${ }^{6}$ Inflammatory mechanisms of inflammatory bowel disease(IBD), arthritis, psoriasis, depression, and atherosclerotic disease processes have attracted the attention of investigators, with elevated levels of inflammatory mediators detected at lesion sites. Inflammation worsens the disease, which in turn exacerbates the inflammation, creating a vicious cycle that poses challenges to treatment. Therefore, we need to make it clear that inflammation plays an important role in the occurrence and development of disease, and compounds with anti-inflammatory effects are the direction to look for therapeutic drugs.

The significant anti-inflammatory activity of curcumin has attracted a lot of researchers' interests and is considered to be one of the natural compounds with the greatest potential in the treatment of diseases. The antiinflammatory mechanism and therapeutic effect of curcumin are the research hotspots. This paper will review the current studies on the anti-inflammatory mechanism of curcumin, curcumin in the treatment of inflammatory bowel disease, arthritis and other diseases, and analyze the relevant studies on improving pharmacokinetics, in order to provide suggestions for further research and application of curcumin in the anti-inflammatory effect.

\section{Anti-Inflammatory Mechanism of Curcumin}

The inflammatory pathway consists of four parts: inducers, sensors, mediators and effectors. The physiological and pathological mechanisms of inflammation caused by different Inflammatory triggers are different and have not yet been 
clarified. $^{7}$ In general, anti-inflammatory effects of drugs mainly include: acting on receptors and signaling pathways, regulating the response of target tissues to inflammatory mediators; reversing the effect of the medium on the target tissue; produce anti-inflammatory mediators and so on. ${ }^{6}$ Curcumin exerts anti-inflammatory effects by regulating inflammatory signaling pathways and inhibiting the production of inflammatory mediators (Figure 2).

Curcumin binds to Toll-like receptors (TLRs) and regulates downstream nuclear factor kappa-B (NF- $\mathrm{kB})$, Mitogenactivated protein kinases (MAPK), Activator Protein 1(AP-1) and other signaling pathways, ${ }^{8-10}$ thereby regulating inflammatory mediators and treating inflammatory diseases. Curcumin can down-regulate NF- $\mathrm{kB}$ through acting on Peroxisome proliferator-activated receptor gamma $(\operatorname{PPAR} \gamma) .{ }^{11,12}$ Curcumin can also play anti-inflammatory effects by regulating The Janus kinase/Signal transducer and activator of transcription (JAK/STAT) inflammatory signaling pathway. ${ }^{13,14}$ In addition, NOD-like receptor pyrin domain-containing 3(NLRP3) inflammasome is cytosolic multiprotein complexes that are involved in the development of a variety of inflammatory diseases. The NLRP3 complex consists of three components: a sensor protein, an apoptosisassociated speck-like protein containing a caspase recruitment domain and a protease caspase-1. Curcumin could directly restrain the assembly of NLRP3 inflammasome, or inhibits the activation of NLRP3 inflammasome by inhibition of NF-kB pathway, which may be one of the mechanisms of curcumin for the treatment of inflammatory diseases. ${ }^{15,16}$

In the studies of inflammatory cells and animals, curcumin decreased levels of pro-inflammatory mediators such as Interleukin-1 (IL-1), IL-1 $\beta$, IL-6, IL-8, IL-17, IL27, Tumor necrosis factor- $\alpha$ (TNF- $\alpha$ ), Inducible nitric oxide synthase (iNOS), NO, Regulated upon activation normal $\mathrm{T}$ cell expressed and secreted factor(RANTES), Granulocyte colony-stimulating factor (G-CSF), and Monocyte chemotactic protein-1 (MCP-1) ${ }^{17-22}$ Clinical trials have also shown that curcumin can reduce inflammatory mediators. ${ }^{23}$ In a Randomized, Double-Blind, Placebo-Controlled Clinical Trial, daily $80 \mathrm{mg}$ curcumin nano-micelle statistically significant improvement in plasma levels of C-reactive protein(CRP), and TNF. ${ }^{24}$

The regulatory effect of curcumin on immune cells is beneficial to its treatment of inflammatory diseases. ${ }^{25,26}$ Curcumin mainly acts on dendritic cells, T helper 17 cell, $\mathrm{T}$ regulatory cell. Th17 is an important pro-inflammatory cell that produces IL-17, IL-22, and IL-23 and promote inflammation response. Treg cells inhibit the inflammatory response. ${ }^{27}$ Changes in the number and function of Th17 and Treg can cause an abnormal immune response, leading to inflammation. Therefore, maintaining Th17/Treg balance is conducive to the maintenance of immune homeostasis and the treatment of inflammatory diseases. ${ }^{28}$ Curcumin inhibits Th17 differentiation, and regulate

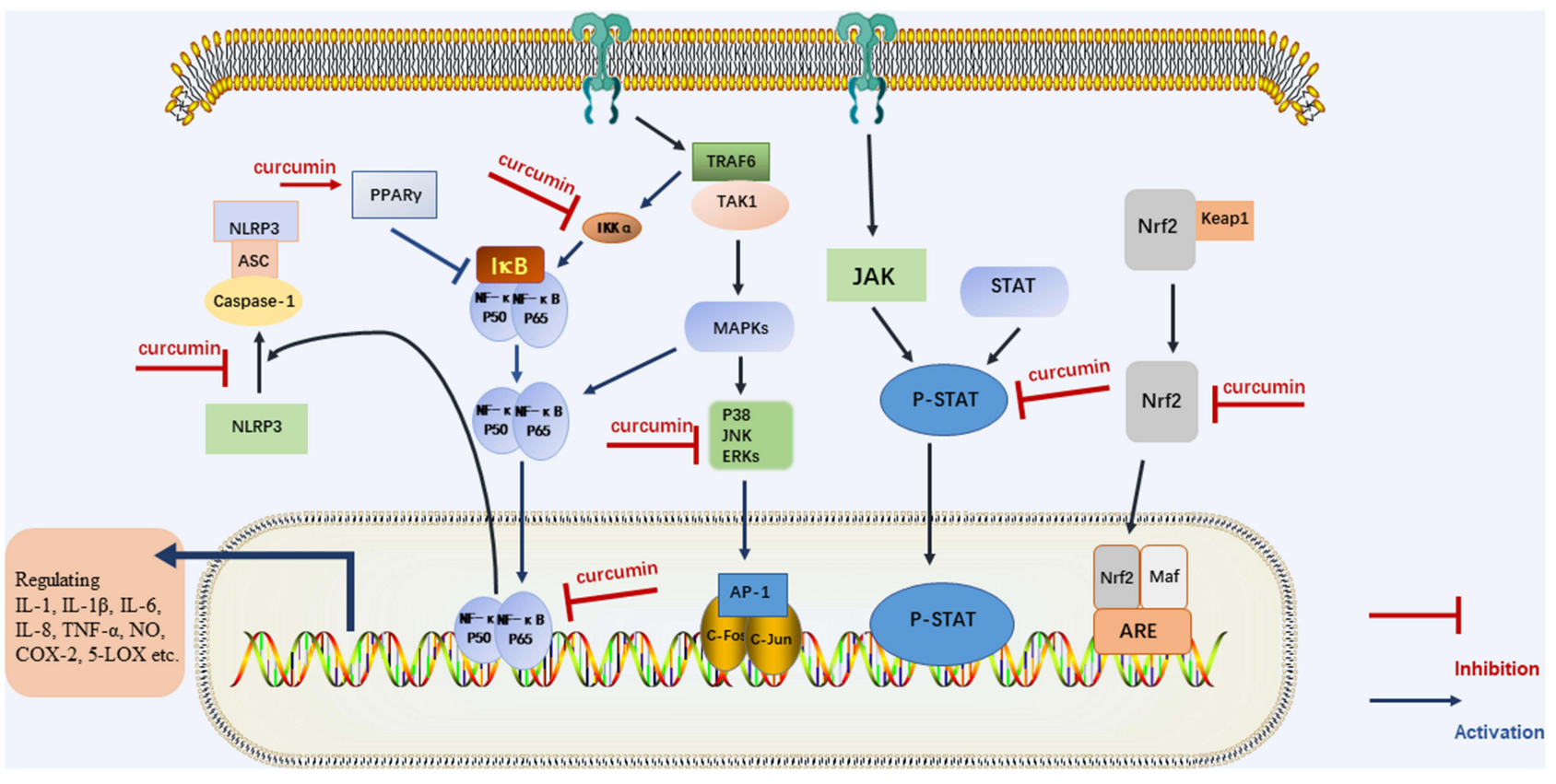

Figure $\mathbf{2}$ The regulatory effect of curcumin on inflammatory signaling pathway. 
Treg/Th17 rebalance is by inhibit the IL-23/Th17 pathway. $^{29,30}$

Oxidative stress is closely related to inflammatory processes. The accumulation of Reactive oxygen species (ROS) leads to oxidative stress, which enhances inflammation by activating transcription factors associated with inflammation. Curcumin reduces ROS production due to its effect on nicotinamide adenine dinucleotide phosphate (NADPH) oxidase and increasing the activity of antioxidant enzymes, and is related to Nrf2-Keap1 pathway. ${ }^{31-33}$ Curcumin reduces inflammation through its antioxidant activity.

\section{Anti-Inflammatory Effects of Curcumin in Several Inflammatory Diseases}

Curcumin has significant anti-inflammatory effects, and a large number of preclinical or clinical researches have studied its effect on inflammatory diseases, among them, inflammatory bowel disease, arthritis, psoriasis, depression, atherosclerosis and COVID-19 are the focus of research hotspots. Current evidences suggest that curcumin is effective in reducing levels of inflammatory mediators, and that curcumin's anti-inflammatory properties may have a beneficial effect on these diseases (Figure 3). In this review, the inflammatory mechanism of above diseases, therapeutic effect and the current application of curcumin are described as follows. The related experimental/animal studies and clinical trials are summarized in Tables 1 and 2.

\section{Effect of Curcumin on Inflammatory Bowel Disease}

IBD is a chronic, recurrent inflammatory disease, mainly including ulcerative colitis (UC) and Crohn's disease (CD). The difference between the two is that CD can affect the gastrointestinal tract anywhere from the mouth to the anus and is typically characterized by transmural inflammation, while UC mainly affects the colonic epithelium. IBD has become a global disease. No matter in Western countries or in newly industrialized countries, the incidence of IBD is on the rise, causing a global economic burden. ${ }^{34}$ Now, the etiology of IBD has not been fully elucidated, and may be related to genetic, environmental factors and immunity.

UC Patients have chronic and recurrent inflammation in the colon, leading to excessive production of proinflammatory factors, which in turn leads to destruction of the intestinal barrier. Gut mucosal barrier impairment in turn aggravates the inflammatory symptoms. In dextran sulfate sodium salt (DSS)-induced colitis mouse models, DSS triggers NLRP3 inflammasome activation through three main mechanisms, including the formation of ROS,

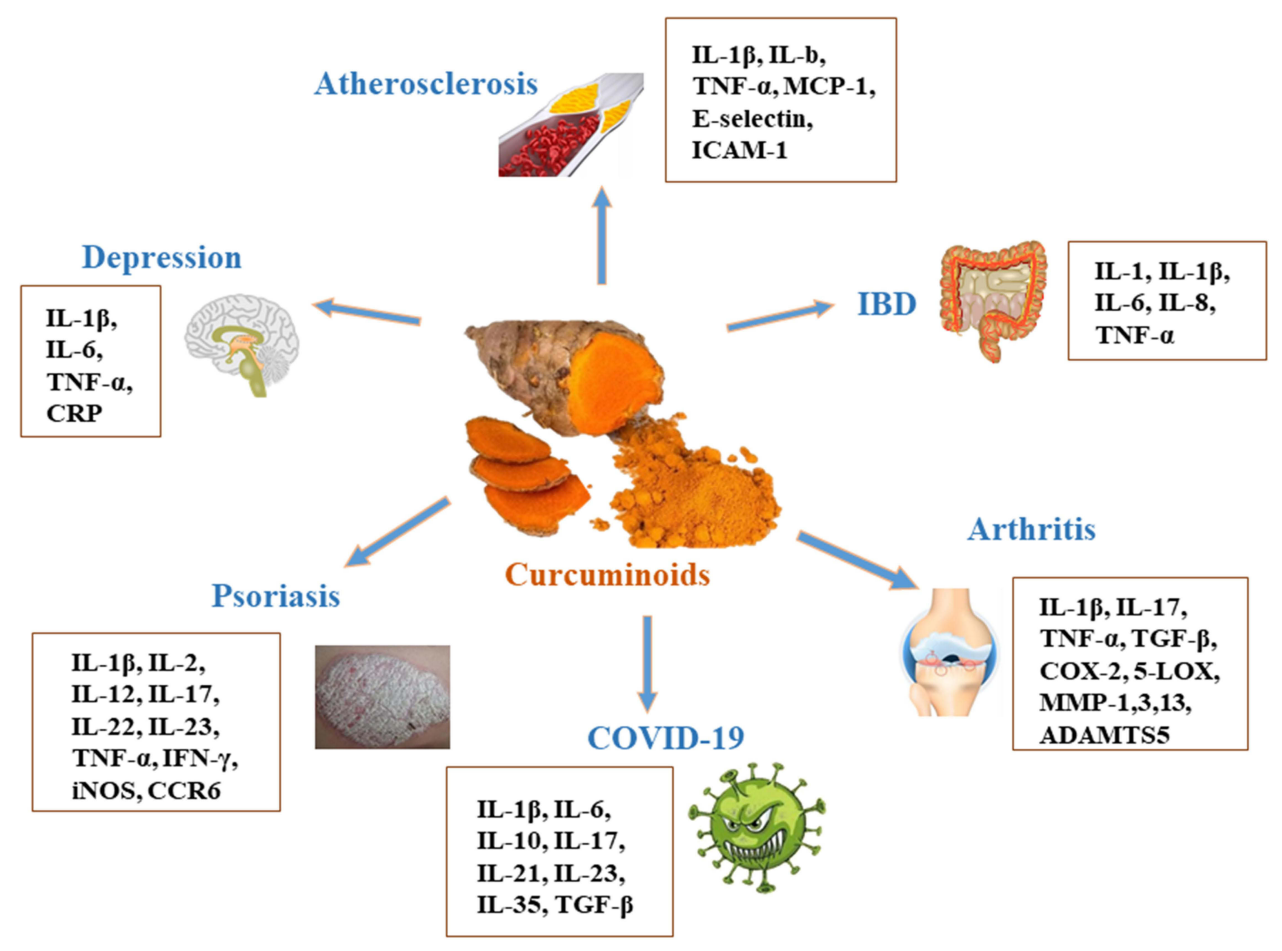

Figure 3 The effect of curcumin on IBD, arthritis, psoriasis, depression and atherosclerosis. 
Table I Summary of Studies on Curcumin with Anti-Inflammatory Effect

\begin{tabular}{|c|c|c|c|c|}
\hline Compounds & Experimental Models & Dosage and Administration & Effects & Ref \\
\hline Curcumin & LPS-induced BV2 cells & $\mathrm{I}, 5$, and $10 \mu \mathrm{M}$ & $\begin{array}{l}\downarrow N O, I L-I \beta, \text { IL-6, iNOS } \\
\uparrow I L-4, \text { IL- I0, Arg-I } \\
\text { promoted microglial polarization } \\
\text { to the M2 phenotype }\end{array}$ & {$[8]$} \\
\hline Curcumin & $\begin{array}{l}\text { Subarachnoid hemorrhage mice } \\
\text { models }\end{array}$ & $100 \mathrm{mg} / \mathrm{kg}$, i.p. & $\begin{array}{l}\downarrow \text { IL-I } \beta, \text { IL-6, iNOS, and TNF- } \alpha, \\
\text { CD86 protein, } \\
\uparrow \text { IL- I0, TGF- } \beta \\
\downarrow \text { TLR4 signaling }\end{array}$ & [9] \\
\hline Curcumin & $\begin{array}{l}\text { Cigarette smoke extract-treated Beas- } \\
2 B \text { cells }\end{array}$ & $2.5,5$ and $7.5 \mu \mathrm{M}$ & $\begin{array}{l}\uparrow \text { PPAR- } \gamma \\
\downarrow \text { NF- } \kappa B\end{array}$ & {$[\mathrm{II}]$} \\
\hline Curcumin & $\begin{array}{l}\text { Cigarette smoke-induced COPD rat } \\
\text { models }\end{array}$ & $100 \mathrm{mg} / \mathrm{kg}$, i.g. & $\begin{array}{l}\uparrow \text { PPAR- } \gamma, \\
\downarrow \text { NF- } \kappa B \text {, inflammation score } \\
\downarrow \text { TNF- } \alpha, \text { IL- } 6\end{array}$ & {$[\mathrm{II}]$} \\
\hline Curcumin & GpI20-induced BV2 cells & $10 \mu \mathrm{M}$ & $\downarrow$ MCP-I, IL-I7 & {$[17]$} \\
\hline Curcumin & $\begin{array}{l}\text { LPS-induced inflammation in vascular } \\
\text { smooth muscle cells }\end{array}$ & $5,10,30 \mu \mathrm{mol} / \mathrm{L}$ for $24 \mathrm{~h}$ & $\begin{array}{l}\downarrow \text { MCP-I, TNF- } \alpha \text {, iNOS, NO } \\
\downarrow \text { ROS }\end{array}$ & [19] \\
\hline Curcumin & $\begin{array}{l}\text { Palmitate-induced inflammation in } \\
\text { skeletal muscle } \mathrm{C} 2 \mathrm{Cl} 2 \text { cells }\end{array}$ & $40 \mu \mathrm{M}$ & $\begin{array}{l}\downarrow \text { TNF- } \alpha, \text { IL-6 } \\
\downarrow \text { ROS }\end{array}$ & [20] \\
\hline Curcumin & TNBS-Induced Colitis Rats & $100 \mathrm{mg} / \mathrm{kg}$, i.g. & $\downarrow$ TLR4, NF-אB, IL-27 & {$[21]$} \\
\hline Curcumin & $\begin{array}{l}\text { dextran sulfate sodium-induced colitis } \\
\text { mice }\end{array}$ & $100 \mathrm{mg} / \mathrm{kg}$, i.g. & $\begin{array}{l}\downarrow \text { IL-6, IL-I7, IL-23 } \\
\uparrow \text { IL-10 regulating the Re- } \\
\text { equilibration of Treg/ThI7 }\end{array}$ & [30] \\
\hline Curcumin & DSS-induced colitis mouse model & $\begin{array}{l}100 \mathrm{mg} / \mathrm{kg} \text {, intraperitoneally } \\
\text { injected }\end{array}$ & $\downarrow$ IL-I $\beta$, IL-6, MCP-I & [35] \\
\hline Curcumin & $\begin{array}{l}\text { DSS-induced ulcerative colitis mice } \\
\text { model }\end{array}$ & $\begin{array}{l}50 \mathrm{mg} / \mathrm{kg} \text {, standard diet } \\
\text { supplemented }\end{array}$ & $\downarrow$ TNF- $\alpha$, IL-6 & [44] \\
\hline Curcumin & DSS-induced acute colitis in mice & $\begin{array}{l}15,30,60 \mathrm{mg} / \mathrm{kg} \text {, } \\
\text { intraperitoneally injected }\end{array}$ & $\begin{array}{l}\downarrow \text { TNF- } \alpha, \text { IL-6, IL- I7 } \\
\uparrow I L-10\end{array}$ & [45] \\
\hline $\begin{array}{l}\text { Curcumin } \\
\text { Curcumin } \\
\text { nanoparticles }\end{array}$ & $\begin{array}{l}\text { Post-traumatic osteoarthritis mouse } \\
\text { model }\end{array}$ & $\begin{array}{l}50 \mathrm{mg} / \mathrm{kg} \text {, i.g. } \\
0.07 \mathrm{mg} \text { of } 10 \mu \mathrm{g} \text { curcumin } / \mathrm{l} \mathrm{mg} \\
\text { nanoparticles, topical application }\end{array}$ & $\begin{array}{l}\downarrow \text { MMP-I, MMP-3, MMP-I3, } \\
\text { ADAMTS5, IL-I } \beta, \text { TNF- } \alpha\end{array}$ & [57] \\
\hline $\begin{array}{l}\text { Acid-activatable } \\
\text { curcumin polymer }\end{array}$ & $\begin{array}{l}\text { Monoiodoacetic acid-induced } \\
\text { osteoarthritis mouse model }\end{array}$ & $\begin{array}{l}2.5,5 \mathrm{mg} / \mathrm{kg} \text {, intramuscular } \\
\text { injection }\end{array}$ & $\downarrow$ IL-I $\beta$, TNF- $\alpha$ & [58] \\
\hline Curcumin & Collagen-induced rat arthritis model & $100,200 \mathrm{mg} / \mathrm{kg}$, oral & $\downarrow$ TNF- $\alpha$, IL-I7, IL-I $\beta$ and TGF- $\beta$ & [59] \\
\hline Curcumin & $\begin{array}{l}\text { Anterior cruciate ligament transection } \\
\text { rat model }\end{array}$ & $\begin{array}{l}50 \mu \mathrm{L}, \\
\text { Intra-articular administration }\end{array}$ & $\downarrow$ IL-I $\beta$, TNF-a & {$[61]$} \\
\hline $\begin{array}{l}\text { Curcumin loaded } \\
\text { hyalurosomes }\end{array}$ & Fibroblast-like synovial cells & & $\begin{array}{l}\uparrow \text { IL-I0 } \\
\downarrow \text { IL-6, IL-I5, TNF-a }\end{array}$ & [68] \\
\hline Curcumin & $\begin{array}{l}\text { Primary rat abdominal macrophages } \\
\text { MSU-induced gouty arthritis rat model }\end{array}$ & $\begin{array}{l}\mathrm{I} \mu \mathrm{M} \\
100,150,200 \mathrm{mg} / \mathrm{kg} \text {, } \\
\text { intraperitoneal administration }\end{array}$ & $\begin{array}{l}\downarrow \text { IL-I } \beta, \text { TNF- } \alpha, \text { NLRP3, caspase- } \\
\text { I }\end{array}$ & [70] \\
\hline
\end{tabular}


Table I (Continued).

\begin{tabular}{|c|c|c|c|c|}
\hline Compounds & Experimental Models & Dosage and Administration & Effects & Ref \\
\hline Curcumin & $\begin{array}{l}\text { Imiquimod-induced differentiated } \\
\mathrm{HaCaT} \text { cells }\end{array}$ & $25,50 \mu \mathrm{M}$ & $\downarrow$ IL-I7, TNF-a, IL-6, IFN- $\gamma$ & [80] \\
\hline Curcumin & Transgenic mouse model of psoriasis & $40 \mathrm{mg} / \mathrm{kg}$ & $\begin{array}{l}\downarrow \text { IFN- } \gamma, \text { TNF- } \alpha, \text { IL-2, IL- I2, IL-22, } \\
\text { IL- } 23\end{array}$ & [82] \\
\hline Curcumin & $\begin{array}{l}\text { TPA-induced KI4-VEGF transgenic } \\
\text { psoriasis }\end{array}$ & $\begin{array}{l}\text { Topical } 50 \mathrm{mg} / \mathrm{cm}^{2} \text { curcumin gel, } \\
\text { twice daily }\end{array}$ & $\downarrow \mathrm{IFN}-\gamma$ & [83] \\
\hline $\begin{array}{l}\text { Curcumin } \\
\text { nanohydrogel }\end{array}$ & imiquimod-induced psoriasis model & & $\downarrow$ TNF- $\alpha$, iNOS & [84] \\
\hline Curcumin & $\begin{array}{l}\text { Chronic unpredictable mild stress- } \\
\text { induced rats model }\end{array}$ & $100 \mathrm{mg} / \mathrm{kg}$, daily & $\begin{array}{l}\downarrow \text { IL-I } \beta, \text { IL-6, TNF- } \alpha \\
\downarrow \text { NF- } \kappa \text { B activation } \\
\downarrow \text { stressed-induced P2X7R/NLRP3 } \\
\text { inflammasome axis activation }\end{array}$ & [102] \\
\hline Curcumin & $\begin{array}{l}\text { Chronic unpredictable mild stress- } \\
\text { induced rats model }\end{array}$ & $20 \mathrm{mg} / \mathrm{kg}$, oral & $\downarrow$ IL-6, TNF- $\alpha$ & [103] \\
\hline Curcumin & CUMS depression model & $40 \mathrm{mg} / \mathrm{kg}$, i.p. & $\downarrow$ IL-I $\beta$ & [104] \\
\hline Curcumin & ApoE-/- mice & $0.1 \% \mathrm{w} / \mathrm{w}$, diet addition & $\begin{array}{l}\downarrow \text { TLR4, IL-I } \beta, \text { TNF- } \alpha \text {, VCAM-I, } \\
\text { ICAM-I, NF- } \kappa \text { B, }\end{array}$ & [122] \\
\hline $\begin{array}{l}\text { Mannich } \\
\text { Curcuminoids }\end{array}$ & TNBS-induced colitis rats model & $40 \mathrm{mg} / \mathrm{kg}$, orally & $\downarrow N F-\kappa B, I L-6$, IL-4, TNF- $\alpha$ & [149] \\
\hline TRB-N0224 & $\begin{array}{l}\text { A rabbit anterior cruciate ligament } \\
\text { transection injury-induced model of } \\
\text { OA. }\end{array}$ & $25,50 \mathrm{mg} / \mathrm{kg} /$ day & $\begin{array}{l}\downarrow I L-I \beta, \text { IL-6, TNF- } \alpha, \text { MMP-9, } \\
\text { MMP-I3 }\end{array}$ & [150] \\
\hline $\begin{array}{l}\text { Curcumin analogue } \\
\text { Al-44 }\end{array}$ & MSU-induced THP-I cell & $3 \mu \mathrm{M}$ & $\downarrow$ TNF- $\alpha$, IL-I $\beta$ & [157] \\
\hline $\begin{array}{l}\text { Curcumin diglutaric } \\
\text { acid }\end{array}$ & $\begin{array}{l}\text { LPS-stimulated RAW } 264.7 \\
\text { macrophage cells }\end{array}$ & $\mathrm{I}, 5,10,20$, and $50 \mu \mathrm{M}$ & $\begin{array}{l}\downarrow \text { NO, IL-6, TNF- } \alpha \text {, iNOS, COX- } \\
2\end{array}$ & [160] \\
\hline $\begin{array}{l}\text { Curcumin- } \\
\text { galactomannoside } \\
\text { (CGM) }\end{array}$ & Acetic acid-induced colitis & $250 \mathrm{mg} / \mathrm{kg}$ bwt & $\begin{array}{l}\downarrow \text { COX-2, PGE2, iNOS, TLR4, IL- } \\
6 \text {, TNF- } \alpha\end{array}$ & {$[|7|]$} \\
\hline $\begin{array}{l}\text { Next Generation } \\
\text { Ultrasol Curcumin } \\
\text { (NGUC) }\end{array}$ & MIA-induced $O A$ & $\begin{array}{l}1100,2200 \mathrm{mg} / \mathrm{kg}(20,40 \mathrm{mg} / \mathrm{kg} \\
\text { of curcuminoids) }\end{array}$ & $\begin{array}{l}\downarrow \text { TNF- } \alpha \text {, IL-I } \beta, \text { IL-6, COMP, CRP, } \\
\text { MMP-3, 5-LOX, COX-2, NF- } \mathrm{B}\end{array}$ & [174] \\
\hline
\end{tabular}

the release of cathepsin $\mathrm{B}$, and the excretion of $\mathrm{K}+$. Stimulated NLRP3 promotes the maturation and secretion of a pro-inflammatory cytokine, IL- $1 \beta$, which is involved in the development of many inflammatory diseases, including IBD. Curcumin significantly protects against severe DSSinduced colitis by inhibiting activation of NLRP3 inflammasomes and production of IL-1 $\beta$, resulting in improved weight loss, reduced disease activity index and increased colon length. ${ }^{35}$ Curcumin can inhibit the production of pro- inflammatory factors such as IL-1, IL-6, IL-8, and TNF- $\alpha$ by regulating the TLR4/NF- $\mathrm{KB} / \mathrm{AP}-1$ signaling pathway, which is beneficial to improve intestinal inflammation in patients with IBD. ${ }^{36,37}$ Curcumin can effectively induce and maintain symptom relief in patients with $\mathrm{UC}$, reduce inflammatory markers and improve the quality of life of patients. $^{38,39}$ Theracurmin has demonstrated significant clinical and endoscopic efficacy and good safety in patients with active mild to moderate Crohn's disease. ${ }^{40}$ 
Table 2 Clinical Trials Regarding Anti-Inflammatory Effects of Curcumin in Treatment of Diseases

\begin{tabular}{|c|c|c|c|c|c|}
\hline Curcumin & Disease & Dose(s) & Duration & Outcome(s) & Ref \\
\hline Curcumin & $\begin{array}{l}\text { Metabolic } \\
\text { syndrome }\end{array}$ & I g daily & 8 weeks & $\downarrow$ TNF- $\alpha$, IL-6, TGF- $\beta$ and MCP-I & [23] \\
\hline Curcumin nanomicelle & $\begin{array}{l}\text { Male factor } \\
\text { infertility }\end{array}$ & 80 mg daily & 10 weeks & $\downarrow$ CRP, TNF- $\alpha$ & {$[24]$} \\
\hline Sinacurcumin ${ }^{\circledR}$ & Osteoarthritis & 80 mg daily & 3 mouths & $\begin{array}{l}\downarrow \text { Visual Analog Score (VAS), CRP, CD4+ } \\
\text { and CD8+ T cells, Th } 17 \text { cells and B cells } \\
\text { frequency }\end{array}$ & {$[25]$} \\
\hline Theracurmin $^{\circledR}$ & $\begin{array}{l}\text { Crohn's } \\
\text { disease }\end{array}$ & $360 \mathrm{mg}$ daily & 12 weeks & $\begin{array}{l}\text { Significant clinical and endoscopic efficacy } \\
\text { together with a favorable safety profile. }\end{array}$ & [40] \\
\hline $\begin{array}{l}\text { IQP-CL-I0I(Each IQP-CL-I0I } \\
\text { softgel contains } 330 \mathrm{mg} \\
\text { proprietary mixture of } \\
\text { curcuminoids and essential } \\
\text { oils.) }\end{array}$ & $\begin{array}{l}\text { Irritable } \\
\text { Bowel } \\
\text { Syndrome }\end{array}$ & Two softgels daily & 8 weeks & $\begin{array}{l}\text { Beneficial in the improvement of IBS } \\
\text { symptom severity, improve quality of life } \\
\text { in patients suffering from abdominal pain } \\
\text { and discomfort. }\end{array}$ & {$[52]$} \\
\hline Curcuma longa extract & $\begin{array}{l}\text { Knee } \\
\text { osteoarthritis }\end{array}$ & $\begin{array}{l}\mathrm{CL} \text { extract } 500 \mathrm{mg} \text { along } \\
\text { with Diclofenac twice a day }\end{array}$ & 4 months & $\begin{array}{l}\text { Suppresses inflammation and brings } \\
\text { clinical improvement in patients of KOA, } \\
\text { which may be observed by decreased } \\
\text { level of IL-I } \beta \text { and VAS/WOMAC scores, } \\
\text { respectively. }\end{array}$ & {$[7 \mid]$} \\
\hline Curcuma longa extract & $\begin{array}{l}\text { Knee } \\
\text { osteoarthritis } \\
\text { and knee } \\
\text { effusion- } \\
\text { synovitis }\end{array}$ & 2 capsules of $C L$, daily & 12 weeks & $\begin{array}{l}\mathrm{CL} \text { was more effective than placebo for } \\
\text { knee pain but did not affect knee } \\
\text { effusion-synovitis or cartilage } \\
\text { composition. }\end{array}$ & [72] \\
\hline $\begin{array}{l}\text { Herbal formulation "turmeric } \\
\text { extract, black pepper, and } \\
\text { ginger" }\end{array}$ & $\begin{array}{l}\text { Knee } \\
\text { osteoarthritis }\end{array}$ & $\begin{array}{l}\text { Curcumin }(300 \mathrm{mg}) \text {, twice } \\
\text { a day }\end{array}$ & 4 weeks & $\downarrow$ PGE2 & [73] \\
\hline Curcumin & $\begin{array}{l}\text { Rheumatoid } \\
\text { arthritis }\end{array}$ & $500 \mathrm{mg}$, twice daily oral & 8 weeks & $\begin{array}{l}\text { Improvement in overall DAS and ACR } \\
\text { scores. }\end{array}$ & [74] \\
\hline Curcuminoid C3 Complex & Psoriasis & $4.5 \mathrm{~g}$ & 12 weeks & $\begin{array}{l}\text { The response rate was low and possibly } \\
\text { due to a placebo effect or the natural } \\
\text { history of psoriasis. }\end{array}$ & [89] \\
\hline Curcumin & $\begin{array}{l}\text { Major } \\
\text { Depression }\end{array}$ & $500-1500 \mathrm{mg} /$ day & 12 weeks & Significant antidepressant effects. & [1।3] \\
\hline SinaCurcumin & COVID-19 & $40 \mathrm{mg}$, twice daily & 2 weeks & Significantly improve recovery time. & [139] \\
\hline Curcumin with Piperine & COVID-19 & $\begin{array}{l}\text { Curcumin }(525 \mathrm{mg}) \text { with } \\
\text { piperine }(2.5 \mathrm{mg}) \text { in tablet } \\
\text { form twice a day. }\end{array}$ & 14 days & $\begin{array}{l}\text { Substantially reduce morbidity and } \\
\text { mortality, and ease the logistical and } \\
\text { supply-related burdens on the healthcare } \\
\text { system. }\end{array}$ & [140] \\
\hline Theracurmin $^{\circledR}$ & $\begin{array}{l}\text { Knee } \\
\text { osteoarthritis }\end{array}$ & $\begin{array}{l}6 \text { capsules of Theracurmin } \\
\text { per day }\end{array}$ & 6 months & $\begin{array}{l}\text { shows great potential for the treatment } \\
\text { of human knee osteoarthritis. }\end{array}$ & [169] \\
\hline $\begin{array}{l}\text { Curcumagalactomannoside } \\
\text { complex (CurQfen) }\end{array}$ & $\begin{array}{l}\text { Knee } \\
\text { osteoarthritis }\end{array}$ & $400 \mathrm{mg}$, daily & 6 weeks & $\begin{array}{l}\text { exerted beneficial effects in alleviating the } \\
\text { pain and symptoms. }\end{array}$ & [I70] \\
\hline
\end{tabular}


Table 2 (Continued).

\begin{tabular}{|c|c|c|c|c|c|}
\hline Curcumin & Disease & Dose(s) & Duration & Outcome(s) & Ref \\
\hline $\begin{array}{l}\text { CuraMed }^{\circledR} \\
\text { Curamin }^{\circledR}\end{array}$ & Osteoarthritis & $\begin{array}{l}\text { 500-mg capsules ( } 333 \mathrm{mg} \\
\text { curcuminoids) } \\
500-\mathrm{mg} \text { capsules ( } 350 \mathrm{mg} \\
\text { curcuminoids and } 150 \mathrm{mg} \\
\text { boswellic acid) taken orally } \\
\text { three times a day }\end{array}$ & 12 weeks & $\begin{array}{l}\text { Reduces pain-related symptoms in } \\
\text { patients with OA. }\end{array}$ & [183] \\
\hline LI730I4F2 & $\begin{array}{l}\text { Knee } \\
\text { osteoarthritis }\end{array}$ & $200,400 \mathrm{mg} /$ day & 90 days & $\begin{array}{l}\text { Significant pain relief, improved physical } \\
\text { function, and quality of life in OA patients. }\end{array}$ & [184] \\
\hline
\end{tabular}

Autophagy is an important intracellular catabolic process, which plays a mitigating role in the occurrence and development of UC. Current studies suggest that the interaction between autophagy, inflammation and gut microbiota affects the disease course of IBD together. ${ }^{41-43}$ Curcumin is derived from natural products, with high safety, has the capacity for anti-inflammatory, antioxidant, and regulating autophagy and gut microbiota. ${ }^{44,45}$ The regulatory relationship among gut microbiota, inflammation and autophagy, as well as their roles in the occurrence and development of IBD, is a new direction to reveal the pathological mechanism of IBD and to search for therapeutic drug targets.

Curcumin is a safe and effective adjuvant agent in the treatment of IBD. ${ }^{36,38,46}$ In patients with IBD, curcumin has a beneficial effect on clinical symptoms, endoscopic relief, reduction of oxidative stress or inflammatory markers. However, due to the lack of unified standards for curcumin administration form, administration method, dosage and model selection indexes, as well as the limited bioavailability of curcumin, there is still no sufficient clinical evidence to prove that curcumin is a therapeutic agent for IBD. Some studies suggested that oral curcumin was no better than placebo in alleviating clinical symptoms of $\mathrm{UC}^{47}$ Now, researchers generally agree that curcumin is used as adjuvant therapy, and when mesalazine is used in the treatment of UC, adding appropriate amount of curcumin can improve the therapeutic effect. ${ }^{48-50}$

Alternatively, curcumin can also play a beneficial role in a more common intestinal disease. ${ }^{51}$ Irritable bowel syndrome(IBS) is a functional bowel disorder that classically presents with symptoms of abdominal pain, bloating, and altered bowel habits of diarrhea or constipation. The Irritable Bowel Syndrome- symptom severity score (IBSSSS) was used to evaluate the effect of curcumin on patients with IBS. Curcumin can effectively improve IBSSSS, abdominal pain and other symptoms, and improve the quality of life of patients. ${ }^{52}$ Research suggest that the beneficial effects of curcumin on IBS may be due to its anti-inflammatory effect. ${ }^{53}$

\section{Effect of Curcumin on Arthritis}

The main types of arthritis are osteoarthritis (OA), rheumatoid arthritis (RA), gouty arthritis. Osteoarthritis, the most common joint disease, is a degenerative joint disease associated with inflammation. Osteoarthritis is more common in people over the age of 50 and in female. ${ }^{54}$ Cartilage, subchondral bone, and synovial inflammation may all play a key role in the pathogenesis of osteoarthritis. After the stimulation of osteoblasts, chondrocytes and synovial cells, inflammatory cytokines such as IL-1 $\beta$, IL-6, TNF- $\alpha$ and matrix degrading enzymes are produced, leading to joint destruction and clinical symptoms such as joint swelling and pain. ${ }^{54,55}$ Matrix metalloproteinase (MMP)1, 3.13 and a disintegrin and metalloproteinase with thrombospondin-like motifs (ADAMTS)-5 are the major matrix degrading enzymes in osteoarthritis. ${ }^{56}$

Curcumin can reduce joint inflammation and alleviate pain symptoms, mainly due to its anti-inflammatory and cartilaginous protective effects. In primary cultured chondrocytes, curcumin inhibited the mRNA expression of proinflammatory mediators IL- $1 \beta$ and TNF- $\alpha$, MMPs 1.3 and 13 , and ADAMTS5, and upregulated the chondroprotective transcriptional regulator $\mathrm{Cbp} / \mathrm{p} 300$ interacting transactivator with ED-rich tail 2(CITED2). ${ }^{57}$ Curcumin reduces the synthesis of inflammatory mediators, such as TNF- $\alpha$, IL-17, IL-1 $\beta$, transforming growth factor- $\beta$ (TGF- $\beta$ ), and cyclooxygenase-2 (COX-2), and reduces the cartilage and synovial inflammation of rat models of arthritis induced by lipopolysaccharide(LPS), Collagen II and Monoiodoacetic 
acid. ${ }^{58-61}$ Curcumin exerts an anti-inflammatory effect by inhibiting TLR4 pathway and its downstream NF- $\kappa \mathrm{B}$ signaling pathway. ${ }^{61,62}$ Activation of $\mathrm{NF}-\kappa \mathrm{B}$ pathway not only down-regulates pro-inflammatory factors, but also inhibits the expression of matrix degrading enzymes. Curcumin inhibited IL-1 $\beta$-induced MMP-1 and MMP-3 production by inhibiting AP-1 and NF- $\mathrm{BB}$ signaling Pathway activation. Moreover, as one of the metabolites of curcumin, tetrahydrocurcumin and curcumin had a similar efficacy for preventing the exacerbation of OA by decreasing the expression of cytokines and MMP3, MMP13 in the articular cartilage. ${ }^{63}$

RA is an inflammatory autoimmune disease characterized by chronic inflammation of the synovial joint that can lead to severe joint injury. IL-10 plays an important role in the development of rheumatoid arthritis. ${ }^{64}$ Curcumin has anti-inflammatory effect and can regulate TLR-4 receptor and its downstream pathway. ${ }^{65}$ Curcumin can downregulate the levels of TNF- $\alpha$, IL-1 $\beta$, IL-6, IL-12, IL-15, and IL- 8 in macrophages, and up-regulate the level of IL10. ${ }^{66-68}$ Curcumin salicylate monoester (FM0807), a curcumin derivative, that incorporates a salicylate into curcumin and retains the $\beta$-dike tone structure. FM0807 might exert its anti-arthritic agent through inhibition of expression of inflammatory factors. ${ }^{66}$

Gouty arthritis, or gout, is a metabolic disorder characterized by recurrent inflammatory arthritis that is caused by hyperuricemia and the deposition of inflammatory monosodium urate (MSU) crystals in the synovium and joints. It often occurs in adults over the age of 40 years. Curcumin effectively alleviates MSU-induced inflammatory response by inhibiting TLR4/NF- $\mathrm{BB}$ signaling pathway and NLRP3 inflammasome activity. ${ }^{69,70}$

Curcumin is a natural anti-inflammatory drug. Numerous preclinical studies have demonstrated its beneficial effect on arthritis. Clinical trials focused on the treatment of knee osteoarthritis. In a clinical trial of turmeric extract in the treatment of knee osteoarthritis, turmeric extract inhibited inflammation and improved clinical symptoms, as well as reduced IL-1 $\beta$ and oxidative stress $[60] .{ }^{71}$ Turmeric extract was more effective than placebo for knee pain, but did not affect knee effusion - synovitis or cartilage composition. ${ }^{72}$ Motahar Heidari-Beni et al produced an herbal formulation consisting of turmeric extract, black pepper and ginger. In patients with knee osteoarthritis, this compound raises prostaglandin E2 (PGE2) levels similar to naproxen. ${ }^{73}$ In a randomized, pilot study, 45 patients diagnosed with RA were randomized into three groups with patients receiving curcumin $(500 \mathrm{mg})$ and diclofenac sodium $(50 \mathrm{mg})$ alone or their combination. Results show that curcumin administration showed the significantly improvement in overall Disease Activity Score and American College of Rheumatology compare with diclofenac sodium. ${ }^{74}$ Clinical trials of curcumin in the treatment of arthritis have produced promising results. However, curcumin is not yet available as a treatment for arthritis due to limited data. Currently curcumin-containing dietary supplements are widely used for joint health. Larger, in-depth studies of arthritis patients are needed in the future.

\section{Effect of Curcumin on Psoriasis}

Psoriasis is a chronic inflammatory skin disease that affects at least one million people worldwide. The etiology of psoriasis is related to genetic, autoimmune and environmental factors. Psoriasis is often accompanied by comorbidities such as psoriatic arthritis, cardiovascular disease, obesity, metabolic syndrome, liver disease, kidney disease, and depression. Their pathogenesis is thought to be related to inflammation. ${ }^{75}$ Dendritic cells are known to play an important role in the initial stage of psoriasis. ${ }^{76}$ The secretion of IL-23 and IL-12 by myeloid dendritic cells activates IL-17-producing T cells, Th22 and Th1 cells, leading to the production of inflammatory cytokines such as IL-17, IFN- $\gamma$, Interferon-gamma (TNF) and IL-22, which in turn activates the psoriasis-associated inflammatory cascade. ${ }^{77}$ This leads to the development of psoriasis, characterized by keratinocyte proliferation, erythema resulting from thickening of the skin, and local tissue infiltration. Curcumin has anti-inflammatory, anti-oxidative and immunomodulatory effects, and can inhibit $\mathrm{T}$ cell activation, proliferation and production of pro-inflammatory factors by acting on MAPKs, AP-1, NF- $\kappa \mathrm{B}$ pathways.

Curcumin can maintain DC in an immature state which, in turn, impacts on antigen presentation, cytokine production and activation of adaptive $\mathrm{T}$ cell responses. Curcumin reduces IL-17 production by CD4(+) T cells. ${ }^{78}$ In peripheral blood mononuclear cells of psoriasis stimulated in vitro, curcumin can effectively inhibit $\mathrm{T}$ cell proliferation, proinflammatory cytokines and multifunction, and inhibit $\mathrm{T}$ cell production of IFN- $\gamma$, IL-17, Granulocyte-macrophage colony stimulating factor (GMCSF) and IL-22. ${ }^{79}$ Curcumin down-regulation proinflammatory cytokines, IL-17, TNF- $\alpha$, IFN- $\gamma$, and IL-6 then inhibits the proliferation of imiquimod-induced differentiated $\mathrm{HaCaT}$ cells. ${ }^{80}$ 
Vascular endothelial growth factor (VEGF) transgenic mice can be used as a model to study psoriasis. ${ }^{81}$ Because in the transgenic rat model of keratin (K) 14-VEGF, the inflammatory skin condition has psoriasis-like cellular and molecular characteristics, including characteristic vascular changes and epidermal changes. Cytokine levels of TNF$\alpha$, IFN- $\gamma$, IL-2, IL-12, IL-22 and IL-23 were reduced to normal level after curcumin treatment. This may be due to the curcumin inhibits currents of Kv1.3 channel and thus inhibits proliferation of $\mathrm{T}$ cells, or curcumin influence MAPKs, AP-1 and NF- $\mathrm{KB}$ signaling pathways in the psoriasis mice. ${ }^{82}$ Furthermore, research shows that curcumin is capable of relieving TPA-induced inflammation by directly down-regulating IFN- $\gamma$ production. ${ }^{83}$ In an imiquimodinduced psoriasis model, curcumin nanohydrogel restored the normal distribution of TJs proteins ZO1 and occludin and reduced the expression of TNF- $\alpha$ and iNOS. ${ }^{84}$ After topical administration to mice, the curcumin could alleviate inflammation symptoms; lower TNF- $\alpha$, IL-17A, IL17F, IL-22, and IL-1 $\beta$ mRNA levels; and lower CC Chemokine receptor 6(CCR6) protein expression. ${ }^{85}$

There have been some clinical trials of curcumin for psoriasis, but the level of evidence is low and the sample size is small. ${ }^{86-88}$ A Phase II, open-label, Simon's twostage trial of $4.5 \mathrm{~g} / \mathrm{d}$ of oral Curcuminoid C3 Complex in plaque psoriasis patients. Oral curcumin was well tolerated, but it was not proven whether the responses were due to a placebo effect or a natural disease remission. ${ }^{89}$ Curcumin has a variety of mechanisms for psoriasis, curcumin can keep dendritic cells in immaturity, to accelerate the anti-inflammatory macrophage phenotype polarization, ${ }^{90}$ inhibiting proinflammatory factor and $\mathrm{T}$ cell, restrain the vascular endothelial growth factor, effect on psoriasis susceptibility genes, ${ }^{91,92}$ and so on, has great potential. Curcumin is derived from natural plant ingredients, which has good safety and can be used for a long time without causing serious toxic and side effects. Nanogels prepared with appropriate substrates can enhance transdermal absorption, and topical curcumin has a good development prospect in the treatment of psoriasis. $^{84}$

\section{Effect of Curcumin on Depression}

Depression is a serious psychological disorder with a global incidence of about $4 \%$. The pathophysiological mechanism of depression is not yet clear, but it is generally believed to be closely related to inflammation, monoaminergic neurotransmitters, neurotrophic factors and the hypothalamic-pituitary-adrenal axis. It is well known that psychological and social stress is an important inducement of depression. Studies have suggested that stress can activate inflammatory response through $\mathrm{NF}-\mathrm{\kappa B}$ and other pathways, and the cytokines produced can affect neurotransmitter metabolism and synaptic plasticity and other processes, thus leading to depression. ${ }^{93}$ Current research evidence shows that inflammation is closely related to depression. ${ }^{94-96}$ In animal models of depression, proinflammatory cytokines TNF- $\alpha$ and IL- 1 were administered to induce depression-like behavior. ${ }^{95,97}$ Therefore, antiinflammatory and anti-cytokine drug therapy may be an effective way to improve and treat depression. ${ }^{98-100}$

Curcumin is found in the traditional Chinese medicine Jieyu-wan and Xiaoyao-san, which are prescribed to manage stress and mood disorders. ${ }^{101}$ Curcumin has antiinflammatory, antioxidant and neurotrophic properties, suggesting it has strong potential for relieving depression. Chronic unpredictable mild stress induced rats showed depressive-like behaviors, and increased cytokines level associated with depression, which is the classic model for studying depression. According to the relevant test results, such as the Social Interaction Test, Sucrose Preference Test, Forced Swimming Test, Open Field Test, and the High Level Maze Test, curcumin treatment successfully corrected the depression-like behavior of stressed rats. ${ }^{102-105}$ Administration of curcumin also decrease mRNA expression of proinflammatory cytokines IL-1 $\beta$, IL-6, and TNF- $\alpha$, through down-regulation IL-1 $\beta$ / NF- $\kappa \mathrm{B}$ signaling, ${ }^{105}$ inhibit the NLRP3 inflammasome activation. ${ }^{102}$ Curcumin improves IL-1 $\beta$-induced neuronal apoptosis by inhibiting the P38 pathway in chronic unpredictable mild stress induced rats. ${ }^{104}$ Curcumin's antiinflammatory effect is one reason for its improvement in depression, but it is not conclusive. In addition to its antiinflammatory properties, curcumin also inhibits the release of monoamine oxidase, serotonin and dopamine, and regulates the hypothalamus pituitary adrenal axis, neurotrophic factors, and hippocampal neurogenesis and neuroplasticity. ${ }^{106-108}$ Curcumin can improve the depressive behavior of ovariectomised rats, as well as fluoxetine and estradiol, which has similar efficacy with fluoxetine and estradiol oestradiol. ${ }^{109}$

Curcumin has shown favorable antidepressant effects in animal models of depression, but clinical trials have not yielded consistent, positive results. ${ }^{101,110-114}$ In a metaanalysis of nine clinical trials, curcumin may improve symptoms of depression and anxiety in patients with 
depression. ${ }^{101}$ In randomized controlled trials and other clinical trial designs, there was no convincing evidence that patients with major depression were better off with different curcumin extracts (doses of 500-1000 mg/d) than with placebo (or without treatment) after 5-8 weeks of monotherapy or antidepressant enhancement therapy. ${ }^{114}$ But in another double-blind, placebo-controlled trial, adjuvant curcumin (doses increased from $500 \mathrm{mg} /$ day to $1500 \mathrm{mg}$ /day) showed a significant difference between curcumin and placebo at weeks 12 and $16 .{ }^{113}$ Due to the low bioavailability of curcumin, the clinical efficacy of curcumin for depression needs to be verified by larger sample trials, and the dosage and usage of curcumin as well as the assessment tools for the severity of depression should be regulated.

\section{Effect of Curcumin on Atherosclerosis}

With the development and progress of society, the incidence of cardiovascular diseases is increasing, which has seriously affected human health. Atherosclerosis is a common cardiovascular disease with complex pathogenesis and close relationship with hypertension, hyperlipidemia, coronary heart disease and other cardiovascular diseases. Atherosclerosis is a disease characterized by mild chronic inflammation of the arterial wall, which is the potential cause of many cardiovascular and cerebrovascular diseases.

Inflammation plays an important role in both atherosclerotic plaque formation and rupture. The modified lipoprotein activates endothelial cells and chemokines mediate the recruitment of adherent monocytes and lymphocytes to the forming lesion site; cytokines and growth factors produced by the inflammatory intima induce the differentiation of monocytes into macrophages accompanied by the upregulation of the scavenger receptors and TLRs; When activated, macrophages form foam-like cells or activate an inflammatory cascade that leads to atherosclerotic plaque formation. TLR4 is a pattern recognition receptor of innate immunity that is involved in the pathogenesis of atherosclerosis. TLR4 is expressed in a number of different cell types present in the atherosclerotic plaque, such as monocytes, neutrophils, mast cells, T lymphocytes, macrophages and so on. TLR4 binds to the ligand and activates the NF- $\mathrm{NB}$ pathway and subsequent pro-inflammatory gene transcription, leading to NLRP3 inflammasome activation, further promoting the inflammatory response and causing instability of atherosclerotic plaques. ${ }^{115}$ Studies have shown that the expression of NLRP3 inflammasome-related genes is significantly increased in human atherosclerotic lesions, which may be activated by the accumulation of lipoproteins in macrophages and dendritic cells, and inflammasomerelated activation leads to increased IL-1 $\beta .^{116}$ Macrophages play a central role in atherosclerosis. Macrophages have two types of proinflammatory (M1) and anti-inflammatory (M2) phenotypes, and both types of macrophages maintain homeostasis in normal tissues. In atherosclerotic plaques, M1 macrophages were dominant, and the related inflammatory cytokines IL-6, iNOS, and IL$1 \beta$ were increased, which worsened the atherosclerotic lesions. Atherosclerotic plaques are mainly composed of macrophages, T cells and monocytes. ${ }^{117}$ Activation of plaque inflammation leads to protease secretion, tissue destruction, and plaque rupture. In turn, thrombosis produces ischemia and infarction, thus can lead to a series of serious and even life-threatening cardiovascular diseases. ${ }^{118,119}$

Currently, two knockout mouse strains with hypercholesterolemia and atherosclerosis have been used to study the rat model of atherosclerosis: apolipoprotein $\mathrm{E}$ homozygous knockout (-/-) (apoE $\left.{ }^{-/}\right)$mouse; LDL receptor $(-/-)\left(\mathrm{Ldlr}^{-/}\right)$ mouse. ${ }^{118}$ Animal studies have shown that curcumin has an anti-atherosclerosis effect, possibly through its antiinflammatory properties. Curcumin reduces the activation of M1 macrophages. ${ }^{120}$ Curcumin regulates the polarization and plasticity of macrophages by affecting TLR4/MAPK/NF- $\kappa \mathrm{B}$ pathway, which is beneficial to reduce atherosclerosis. ${ }^{121,122}$ In $\mathrm{ApoE}^{-/-}$mice fed a high-fat diet supplemented with $0.1 \%$ curcumin significantly decreased TLR4 expression in atherosclerotic plaques and reduced the development of atherosclerosis. In addition, curcumin supplementation can inhibit the

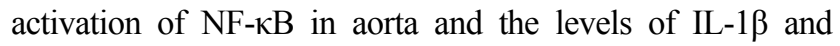
TNF- $\alpha$ in aorta and serum. ${ }^{122}$ Activation of the NF- $\kappa B$ pathway leads to activation of NLRP3 inflammasome. Inhibition of NLRP3 inflammasome improves atherosclerotic lesions in $\mathrm{ApoE}^{-/-}$rats, ${ }^{123}$ and anti-inflammatory therapy targeting IL$1 \beta$ reduces the recurrence rate of cardiovascular events. ${ }^{124}$ Curcumin can inhibit NF- $\kappa \mathrm{B}-$ mediated NLRP3 expression, thereby inhibiting vascular smooth muscle cell migration, and alleviating hypertension, vascular inflammation and vascular remodeling in spontaneously hypertensive rats, which is beneficial to cardiovascular diseases including atherosclerosis. ${ }^{125}$ In ApoE ${ }^{-/-}$mice, atorvastatin calcium and curcumin synergistically inhibited adhesion molecules and plasma lipid levels, reducing foam cell formation and inflammatory cytokines secretion by blocking monocyte migration to the intima. ${ }^{126}$ 
Curcumin has significant efficacy in the treatment of atherosclerosis in animal models, but the relevant clinical evidence is insufficient. Clinical evidence in nonatherosclerotic populations suggests that curcumin can reduce lipid levels and inflammatory responses, as it did in a mouse model. ${ }^{127}$ A meta-analysis of 20 randomized controlled trials with 1427 participants suggested a significant decrease in plasma concentrations of triglycerides and an elevation in plasma high-density lipoprotein cholesterol (HDL-C) levels. ${ }^{128}$ However, in another metaanalysis of clinical trials related to the effect of curcumin on lipid levels, curcumin supplementation did not show a significant effect on serum total cholesterol, low-density lipoprotein cholesterol (LDL-C), triglyceride, and HDL-C levels. ${ }^{129}$ To date, there is a clinical trial that investigates the anti-inflammatory effect of curcumin on atherosclerosis with Curcumin Supplementation, but the status and results of the tests are unknown (NCT02998918). Due to the lack of relevant clinical trials and inconsistent results, more comprehensive clinical trials are needed in the future to better demonstrate the beneficial effects of curcumin on patients with atherosclerosis. The anti-inflammatory properties of curcumin may be the focus of research and observation.

\section{Effect of Curcumin on COVID-19}

Coronavirus disease 19 (COVID-19/2019-nCoV) is an infectious disease, caused by the severe acute respiratory syndrome coronavirus 2 (SARS-CoV-2). As of 12th August 2021, the cumulative cases of COVID-19 are 205,549,209, cumulative death cases are 4,337,638. ${ }^{130}$ The clinical manifestations of COVID-19 including acute respiratory distress syndrome (ARDS), typical pneumonia, and multi-organ failure. ${ }^{131}$ ARDS is the leading cause of COVID-19 mortality, mostly due to cytokine storm syndrome. Patients with COVID-19 showed high levels of inflammatory cytokines (TNF, IL-1 $\beta$, IL-6, IL-8), colonystimulating factors (G-CSF and GM-CSF) and inflammatory chemokines (MCP1, IP10, and MIP1 $\alpha$ ). ${ }^{132-134}$ Thus, suppressing the elevated inflammatory response that occurs during COVID-19 may be useful in preventing the severity of the disease. Curcumin, a natural compound with anti-inflammatory effect, could as an adjuvant drug in COVID-19 treatment. ${ }^{135}$

As described in the previous section, it is clear that curcumin may play an anti-inflammatory role by regulating inflammatory mediators and immune cells. Nanocurcumin can regulate the rate of increase of inflammatory cytokines, especially IL-1 $\beta$ and IL-6 mRNA expression and cytokine secretion in COVID-19 patients, which may lead to improved clinical manifestations and overall recovery. ${ }^{136}$ Compared to the placebo group, curcumin could reduce the frequency of Th17 cells, Treg and their related inflammatory factors in both mild and severe COVID-19 patients. $^{137,138}$ In addition to antiinflammatory effect, curcumin can also play an antiviral role by inhibiting SARS-CoV-2 entry into cells and inhibiting viral proliferation. Curcumin has a variety of pharmacological effects and high safety, which makes it an adjunctive drug for the treatment of COVID-19.

In an open label nonrandomized clinical trial, oral nano-formulation of curcumin with dose of $80 \mathrm{mg}$ twice daily could significantly fasten the resolution time of COVID-19-induced symptoms, improve oxygenation, and reduce hospital stay time in comparison with control group. ${ }^{139}$ In addition, orally administered curcumin with piperine as adjuvant therapy in COVID-19 treatment could substantially reduce morbidity and mortality, improve the clinical symptoms. ${ }^{140}$

\section{Limitations and Countermeasures of Curcumin in the Treatment of Diseases}

\section{Limitations}

The above descriptions fully illustrate that curcumin has significant anti-inflammatory effects, and has great potential in the treatment of IBD, arthritis, psoriasis and other diseases mentioned above, with broad application prospects. However, in clinical application, the antiinflammatory effect of curcumin is not ideal, and curcumin has not been marketed as a therapeutic drug, mainly due to the pharmacokinetic limitations of curcumin. After oral administration of curcumin, most of it is excreted with metabolites and only a small amount enters the bloodstream for utilization, which is significantly lower than the concentration required to inhibit most of the antiinflammatory targets of curcumin. ${ }^{141}$

The process of drugs in vivo determines the fate of drugs. Appropriate rates of absorption, distribution, metabolism and excretion make drugs act on the human body and play a therapeutic role. Low water solubility, poor absorption, elimination and rapid metabolism limit the utilization of curcumin. The water solubility of curcumin is poor and its physical and chemical properties are unstable Only a small amount of curcumin is dissolved in the gastrointestinal tract 
and the effective components are limited. Curcumin is a strong hydrophobic compound with solubility of about 11ng/ mL (https://pubchem.ncbi.nlm.nih.gov/compound/cur cumin). Curcumin is extremely unstable in alkaline environment, resulting in degradation and autooxidation products such as ferulic acid, feruloylmethane, vanillin and bicyclopentadione. ${ }^{142,143}$ Absorption is the process by which a drug enters the bloodstream from the administration site, and curcumin is poorly absorbed from the gastrointestinal tract. Oral curcumin of $12 \mathrm{~g}$ / day is considered to be the maximum safe dose of curcumin, but the final serum curcumin level at this time is only about $50 \mathrm{ng} / \mathrm{mL}{ }^{144}$ This may be due to P-glycoprotein action and liver first pass effect. Curcumin is a substrate for P-glycoprotein, a transmembrane ATP-dependent drug effluence pump that expel curcumin from the intestinal membrane, thereby limiting its permeability. ${ }^{145}$ In addition, the hepatic first-pass effect causes some curcumin to be metabolized in the intestinal mucosa and liver, leading to reduced drug absorption. ${ }^{146}$ The rapid metabolism of curcumin is one of the main causes of poor bioavailability. After entering the blood, curcumin is rapidly metabolized as an inactive substance. Curcumin is reduced to di-, tetra-, hexa- and octahydrocurcumin after I metabolism, then, the above forms, as well as curcumin, demethylcurcumin and bimethylcurcumin, are metabolized in the II phase to conjugate glucuronide and sulfate to form non-bioactive glucuronide and sulfate conjugates. ${ }^{145,147}$ The related degradations and metabolites of curcumin are shown in Figure 4.

\section{Countermeasures}

Improve the bioavailability and stability of the curcumin is curcumin research hot spot and the basis for the development of curcumin related preparation. The current research mainly concentrated in curcumin derivatives and prodrug, pharmaceutical strategies, and combination drug therapy, in order to make curcumin in the target position and to play a better therapeutic effect.

\section{Derivatives and Prodrugs of Curcumin}

Structural modification and analogues synthesis of natural products are important strategies for drug discovery. In order to improve the properties of curcumin, the main direction for the development of curcumin preparation is to use curcumin as the parent nucleus to modify the structure and synthesize analogues. A large number of curcumin analogues, derivatives and prodrugs have been prepared, some of which have improved their physicochemical properties and have significant antiinflammatory effects. ${ }^{148}$

The $\beta$-diketone portion of curcumin is thought to be responsible for its instability, rapid degradation and low bioavailability. At present, the structural modification and modification strategies of curcumin mainly include: modification of active methylene; introducing groups in the benzene ring; preparation of single carbonyl derivatives.

The introduction of several functional groups into the active methylene part of curcumin attracted the attention of researchers. For example, Mannich curcuminoids are attached with aryl groups to curcumin active methylene to enhance the stability of $\beta$-dione and thus enhance the biological activity. Among them, C142 or C150 showed strong anti-inflammatory activity in TNBS induced colitis model. ${ }^{149}$ TRB-N0224 introduces N-phenylformamide onto the active dimethyl and has a 1,3-diketone component similar to tetracycline and the inherent antiinflammatory properties of curcumin itself, regulating the levels of matrix metalloproteinases and cytokines. ${ }^{150}$ The stability of the compound can also be enhanced by the substitution of the active methylene with nitrogen to form a pyridine ring. ${ }^{151}$ The two benzene rings of curcumin are the basis of the antioxidant activity of curcumin. Therefore, attaching $\mathrm{Br}, \mathrm{F}, \mathrm{NO} 2, \mathrm{OH}, \mathrm{CH} 3$ and other groups to the benzene ring is a method to improve the biological activity of curcumin, which is of great significance. ${ }^{152}$ The structure-activity relationship of various groups on the benzene ring affects the physicochemical properties and activity of the compounds. The pharmacokinetic properties of curcumin are improved by adding electron-withdrawing groups, which increase the acidity of the enol system. CURC-MPEG454 was modified with polyethylene glycol to increase its solubility and improve the physicochemical properties of curcumin. ${ }^{153}$

Now, mono-carbonyl derivatives are a major direction in the structural modification of curcumin. In the structural design of mono-carbonyl curcumin derivatives, ketenone $e^{154}$ is commonly used to replace $\beta$-dione, and can also be combined with cyclopentanone, cyclohexanone, ${ }^{155,156}$ 4-piperidone ${ }^{157}$ or N-substituted -4-piperidone. ${ }^{158,159}$ At the same time, the "ortho effect" of the ortho substituents on the benzene ring is emphasized and utilized. It is beneficial to improve the biological activity by attaching $\mathrm{F}, \mathrm{Br}, \mathrm{NO} 2, \mathrm{CF} 3$ groups on the ortho of the benzene ring. C66, a mono-carbonyl derivative of curcumin, is ortho-bonded to the benzene ring with CF3, which plays an anti-inflammatory role by inhibiting 
A<smiles>COc1cc(/C=C/C(=O)CC(=O)/C=C/c2ccc(O)c(OC)c2)ccc1O</smiles><smiles>COc1cc(/C=C/C(=O)/C=C(O)/C=C/c2ccc(O)c(OC)c2)ccc1O</smiles>

Curcumin
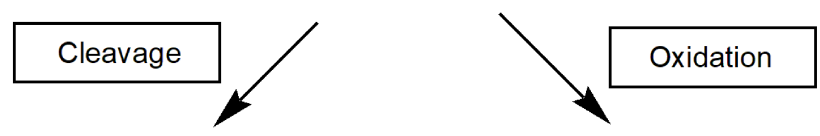<smiles>COc1cc(/C=C/C(=O)O)ccc1O</smiles><smiles>COc1cc(/C=C/C(C)=O)ccc1O</smiles><smiles>COc1cc(C=O)ccc1O</smiles><smiles>COc1cc(OC2OC(c3ccc(O)c(OC)c3)C3C(=O)C=C(O)C23)ccc1O</smiles>

Bicyclopentadione

B<smiles>COc1cc(/C=C/C=C(O)/C=C/C(=O)/C=C/c2ccc(O)c(OC)c2)ccc1O</smiles><smiles>COc1cc(/C=C/C(O)=C/C(=O)CCc2ccc(O)c(OC)c2)ccc1O</smiles><smiles>COc1cc(CCC(=O)C=C(O)CCc2ccc(O)c(OC)c2)ccc1O</smiles><smiles>COc1cc(CCC(=O)CC(O)CCc2ccc(O)c(OC)c2)ccc1O</smiles><smiles></smiles>
Hexahydrocurcumin<smiles>COc1cc(/C=C/C(O)=C/C(=O)/C=C/c2ccc(OC(O)C(O)C(=O)O)c(OC)c2)ccc1O</smiles><smiles>COc1cc(CCC(O)CC(=O)CCc2ccc(OC(O)C(O)COC(=O)O)c(OC)c2)ccc1O</smiles>

Figure 4 Chemical structure of curcumin-related products. (A) Curcumin degradation products; (B) curcumin metabolites.

the JNK pathway. ${ }^{155}$ Some of the mono-carbonyl derivatives showed excellent anti-inflammatory properties. Two ortho-trifluoromethoxy-substituted 4-piperidone- containing mono-carbonyl curcumin derivatives exhibited excellent anti-inflammatory effects in DSS-induced mouse colitis models. They effectively inhibit ROS, COX-2, IL- 
$1 \beta$ and TNF- $\alpha$ levels, phosphorylation of MAPKs, and nuclear translocation of $\mathrm{p} 65 .{ }^{158}$

The prodrug refers to the chemical compound which has no activity in vitro or little activity after the chemical structure modification of the drug and plays a role by releasing the active drug through enzymatic or nonenzymatic transformation in vivo. The anti-inflammatory prodrugs of curcumin mainly include curcumin diglutaric acid (CurDG), ${ }^{160,161}$ curcumin diethyl disuccinate (CurDD), ${ }^{162,163}$ and curcumin diethyl diglutarate (CurDDG). ${ }^{164}$ Compared with curcumin, it has higher bioavailability and pharmacological activity, and has the potential to be further developed as therapeutic drugs. Curcumin diglutamic acid (CURDG) was synthesized by ether bond between curcumin and glutaric acid, which significantly improved water solubility. ${ }^{161}$ Compared with curcumin, CURDG exhibited better antiinflammatory activity in LPS-stimulated RAW 264.7 macrophage cells and carrageenan-induced mouse paw edema model. ${ }^{160}$ In LPS-induced RAW 267.4 macrophages, the anti-inflammatory activity of CURDDG was stronger than that of curcumin. CurDDG significantly decreased the expression of TNF- $\alpha$ and IL- 6 , decreased the levels of COX-2 and iNOS, and decreased the phosphorylation of $\mathrm{p} 38$, JNK and ERK1/2. ${ }^{164}$ Although CURDDG bypasses the Phase II metabolism of curcumin through gluconaldification and sulfation, its water solubility is lower than that of curcumin, limiting its clinical application. Therefore, coating CurDDG with polymer to prepare nanoparticles may be an effective measure to improve the water solubility of CurDDG. ${ }^{165}$

\section{Pharmaceutical Strategies}

Improving the absorption, distribution, metabolism and excretion of drugs by pharmaceutical strategies is an important approach to drug development. At present, the measures to improve the bioavailability of curcumin mainly include the addition of lipids, the adsorption and dispersion of substrates, the reduction of particle size, and the preparation of nano preparations. ${ }^{147}$ Using these techniques, a large number of curcumin preparations have been marketed as dietary supplements, which are popular with the general public for the improvement and maintenance of joint and cardiovascular health. Now, the common curcumin preparations on the market include BCM- $95^{\circledR}$, C3Complex ${ }^{\circledR}$, Meriva $^{\circledR}$, Theracurmin $^{\circledR}$, CurQfen ${ }^{\circledR}$, Theracurmin $^{\circledR}$, Longvida ${ }^{\circledR}$, etc.
Theracurmin is a colloidal dispersion of nanoparticles, which contains $10 \mathrm{w} / \mathrm{w} \%$ curcumin, $2 \%$ of other curcuminoids, $46 \%$ of glycerin, $4 \%$ of chama, and $38 \%$ of water. The mean particle size of Theracurmin (D50\% diameter) was $0.19 \mu \mathrm{m}$. The mean particle size of curcumin powder was $22.75 \mu \mathrm{m}$. Theracurmin can be dissolved in water, greatly improving the bioavailability of Theracurmin. ${ }^{166}$ Compared with curcumin, Theracurmin can significantly inhibit NF- $\kappa \mathrm{B}$ transcriptional activity, and then regulate the expression of pro-inflammatory factors to play an anti-inflammatory role. ${ }^{167}$ Currently, Theracurmin is used as a dietary supplement to inhibit alcoholism and protect the liver, which is manifested by a reduction in acetaldehyde concentration in the blood $^{166}$ and is often used as a hangover agent. Theracurmin is believed to be beneficial to the improvement of cognitive impairment, ${ }^{168}$ clinical symptoms of CD patients, ${ }^{40}$ and joint health ${ }^{169}$ in drug research.

Curcumagalactomannoside complex (CurQfen) has been used for short-term relief of pain and symptoms in patients with arthritis. ${ }^{170}$ In the acetic acid induced ulcerative colitis model, curcumagalactomannoside significantly enhanced antioxidant activity, decreased the level of inflammatory mediators, and inhibited the expression of inflammatory markers. ${ }^{171}$ The amphiphilicity of phospholipids can improve the gastrointestinal absorption of curcumin. Studies have showed that the biological activity of the phospholipid complex is 5 times higher than that of ordinary curcumin, and the absorption rate is higher. A lecithin delivery system(Meriva ${ }^{\circledR}$ ) effectively relieves and treats OA. ${ }^{172,173} \mathrm{~A}$ novel curcumin formulation consisting of $95 \%$ curcumin extract, phospholipids, monoglycerides, and acidifiers shows better bioavailability and treatment for MIA-induced OA. ${ }^{174}$

Curcumin nanocarriers are the focus of research at present. Due to the high surface area to volume ratio provided by nanocarriers, the solubility and dissolution rate of drugs can be improved. In addition, small particle sizes can prolong the maintenance time of drugs in the systemic circulation, alter drug distribution, and allow drug targeting and trans-barrier transport. ${ }^{144}$ Curcumin is a highly hydrophobic compound, and a large number of studies have been conducted on its nano preparations, in order to improve the water solubility of curcumin, enhance transdermal absorption, and target positioning. Common curcumin nanocrystals include liposomes, polymer particles/micelles, nanoemulsions, nanogels, nanocrystals, solid liposome nanoparticles, etc. ${ }^{144,145,175}$ At present, there are 
many kinds of carriers and preparation methods of curcumin nanometer preparations, and they are often modified to obtain the desired properties. ${ }^{176,177}$ For example, using hyaluronic acid to modify the surface of curcumin nanoparticles can maintain a high level of curcumin in the colon tissue, reduce the proinflammatory factors and reduce the inflammatory response in the colon, which is conducive to the treatment of ulcerative colitis. ${ }^{178,179}$ In some inflammatory diseases with superficial disease sites, such as psoriasis and arthritis, nano-emulsion and nanogel can enhance the penetration and accumulation of curcumin in the skin through local administration, which can be used as a direction of preparation research. ${ }^{57,180}$ There are many related preparations with varying quality, which will not be described in detail in this paper.

\section{Combination Drug Therapy}

Combination drug therapy refers to the simultaneous or successive application of two or more drugs for the purpose of treatment. In the application of curcumin, combination therapy is an effective method to improve pharmacokinetics and anti-inflammatory effect of curcumin. Curcumin is used in combination with natural ingredients such as emu oil, tetramethylpyrazine, resveratrol, and Vitamin D to enhance its anti-inflammatory effects. ${ }^{181}$ Piperine is an effective inhibitor of gluconaldification and p-glycoprotein. Combined with piperine, curcumin can synergistically improve anti-inflammatory and antioxidant activity. ${ }^{145}$ Combinations of curcumin with piperine and quercetin have been successfully used for the bioenhancement of curcumin. Frankincense exerts antiinflammatory effects by inhibiting leukotriene synthesis, cyclocythase $1 / 2$ and $\mathrm{c}(5-\mathrm{LOX}) .{ }^{182}$ The combination of curcumin complex and frankincense is effective in alleviating pain related symptoms in patients with osteoarthritis, possibly due to the synergistic effect of curcumin and boswellic acid. ${ }^{183}$ Li73014F2 is a novel compound prepared from the extracts of Terminalia chebula fruit, Curcuma longa rhizome and Boswellia serrata gum resin, which has synergistic inhibitory effect on 5-LOX. In clinical trials, LI73014F2 significantly reduced pain and improved physical function and quality of life in patients with osteoarthritis. ${ }^{184}$ Currently, the use of curcumin alone in the treatment of diseases is limited, and it has achieved good results as an adjuvant therapy, possibly because of the synergistic effect of curcumin when used in combination with other drugs. For example, the Mesalazine adjuvant curcumin has been shown to be effective and safe in inducing clinical remission, endoscopic remission, and endoscopic improvement in ulcerative colitis. ${ }^{48}$

\section{Conclusion}

In conclusion, curcumin has good anti-inflammatory properties, and curcumin regulates NF- $\mathrm{KB}, \mathrm{MAPK}, \mathrm{AP}-1, \mathrm{JAK} /$ STAT and other signaling pathways, and inhibiting the production of inflammatory mediators. Curcumin in the treatment of IBD, arthritis, psoriasis, depression and atherosclerosis and other diseases, can reduce inflammatory response, effectively improve symptoms, play a role in the treatment of diseases. Now, the pharmacokinetics and anti-inflammatory effects of curcumin have been improved to some extent by the structural modification and modification of curcumin, preparation research and drug combination therapy. Among them, curcumin dietary supplement or adjuvant drug has significant therapeutic effect, which is the most feasible way for curcumin application at present.

\section{Abbreviations}

IBD, inflammatory bowel disease; TLR, Toll-like receptors; NF-kB, Nuclear factor kappa-B; MAPKs, Mitogenactivated protein kinases; AP-1, Activator Protein 1; PPAR $\gamma$, Peroxisome proliferator-activated receptor gamma; JAK/STAT, The Janus kinase/Signal transducer and activator of transcription; NLRP3, NOD-like receptor pyrin domain-containing 3 ; IL-1, Interleukin-1; TNF- $\alpha$, Tumor necrosis factor- $\alpha$; iNOS, Inducible nitric oxide synthase; RANTES, Regulated upon activation normal $\mathrm{T}$ cell expressed and secreted factor; G-CSF, Granulocyte colony-stimulating factor; MCP-1, Monocyte chemotactic protein-1; CRP, C-reactive protein; ROS, Reactive oxygen species; NADPH, Nicotinamide adenine dinucleotide phosphate; UC, Ulcerative colitis; CD, Crohn's disease; DSS, dextran sulfate sodium salt; IBS, Irritable bowel syndrome; IBS-SSS, Irritable Bowel Syndrome- symptom severity score; OA, osteoarthritis; RA, rheumatoid arthritis; MMP, matrix metalloproteinase; ADAMTS, a disintegrin and metalloproteinase with thrombospondin-like motifs; CITED2, Cbp/p300 interacting transactivator with EDrich tail 2 ; TGF- $\beta$, transforming growth factor- $\beta$; COX-2, cyclooxygenase-2; LPS, lipopolysaccharide; MSU, monosodium urate; PGE2, prostaglandin E2; IFN- $\gamma$, Interferongamma; GM-CSF, Granulocyte-macrophage colony stimulating factor; VEGF, Vascular endothelial growth factor; CCR6, CC Chemokine receptor 6; apoE-/-, apolipoprotein E homozygous knockout (-/-); Ldlr-/-, LDL receptor $(-/-)$; HDL-C, high-density lipoprotein cholesterol; LDL- 
C, low-density lipoprotein cholesterol; 5-LOX, 5-lipoxygenase; COVID-19, Coronavirus disease 19; SARS-CoV -2 , severe acute respiratory syndrome coronavirus 2; ARDS, acute respiratory distress syndrome.

\section{Acknowledgments}

The authors acknowledge financial supports from the National special fund for intangible cultural heritage protection which organized by ministry of culture and tourism of the people's Republic of China, fellowship of China Postdoctoral Science Foundation (no. 2020M673567XB), Key R \& D projects (no. 20ZDYF1642) which organized by Science \& Technology Department of Sichuan Province, Xinglin Scholar Research Premotion Project of Chengdu University of TCM (no. BSH2019026) and the Open Research Fund of Chengdu University of TCM State Key Laboratory of Characteristic Chinese Medicine Resources in Southwest China (no. 2020QNJS005).

\section{Disclosure}

ChangJiang $\mathrm{Hu}$ is an employee of Neo-Green Pharmaceutical Co., Ltd. The authors report no other potential conflicts of interest for this work.

\section{References}

1. Lestari ML, Indrayanto G. Curcumin. Profiles Drug Subst Excip Relat Methodol. 2014;39:113-204.

2. Ammon HP, Wahl MA. Pharmacology of Curcuma longa. Planta Med. 1991;57(1):1-7. doi:10.1055/s-2006-960004

3. Vaughn AR, Branum A, Sivamani RK. Effects of Turmeric (Curcuma longa) on Skin Health: a Systematic Review of the Clinical Evidence. Phytother Res. 2016;30(8):1243-1264. doi:10.1002/ptr.5640

4. Limketkai BN, Wolf A, Parian AM. Nutritional interventions in the patient with inflammatory bowel disease. Gastroenterol Clin North Am. 2018;47(1):155-177. doi:10.1016/j.gtc.2017.09.007

5. Tabrizi R, Vakili S, Akbari $M$, et al. The effects of curcumin-containing supplements on biomarkers of inflammation and oxidative stress: a systematic review and meta-analysis of randomized controlled trials. Phytother Res. 2019;33(2):253-262. doi:10.1002/ ptr.6226

6. Medzhitov R. Inflammation 2010: new adventures of an old flame. Cell. 2010;140(6):771-776. doi:10.1016/j.cell.2010.03.006

7. Medzhitov R. Origin and physiological roles of inflammation. Nature. 2008;454(7203):428-435. doi:10.1038/nature07201

8. Zhang J, Zheng Y, Luo Y, Du Y, Zhang X, Fu J. Curcumin inhibits LPS-induced neuroinflammation by promoting microglial M2 polarization via TREM2/ TLR4/ NF-kappaB pathways in BV2 cells. Mol Immunol. 2019;116:29-37.

9. Gao Y, Zhuang Z, Lu Y, et al. Curcumin Mitigates Neuro-Inflammation by Modulating Microglia Polarization Through Inhibiting TLR4 Axis Signaling Pathway Following Experimental Subarachnoid Hemorrhage. Front Neurosci. 2019;13:1223. doi:10.3389/fnins.2019.01223
10. Rahimifard M, Maqbool F, Moeini-Nodeh S, et al. Targeting the TLR4 signaling pathway by polyphenols: a novel therapeutic strategy for neuroinflammation. Ageing Res Rev. 2017;36:11-19. doi:10.1016/j.arr.2017.02.004

11. Li Q, Sun J, Mohammadtursun N, Wu J, Dong J, Li L. Curcumin inhibits cigarette smoke-induced inflammation via modulating the PPARgamma-NF-kappaB signaling pathway. Food Funct. 2019;10(12):7983-7994. doi:10.1039/C9FO02159K

12. Zhu T, Chen Z, Chen G, et al. Curcumin Attenuates Asthmatic Airway Inflammation and Mucus Hypersecretion Involving a PPARgamma-Dependent NF-kappaB Signaling Pathway In Vivo and In Vitro. Mediators Inflamm. 2019;2019:4927430. doi: $10.1155 / 2019 / 4927430$

13. Ashrafizadeh M, Rafiei H, Mohammadinejad R, Afshar EG, Farkhondeh T, Samarghandian S. Potential therapeutic effects of curcumin mediated by JAK/STAT signaling pathway: a review. Phytother Res. 2020;34(8):1745-1760. doi:10.1002/ptr.6642

14. Kahkhaie KR, Mirhosseini A, Aliabadi A, et al. Curcumin: a modulator of inflammatory signaling pathways in the immune system. Inflammopharmacology. 2019;27(5):885-900. doi:10.1007/s10787-019-00607-3

15. Hasanzadeh S, Read MI, Bland AR, Majeed M, Jamialahmadi T, Sahebkar A. Curcumin: an inflammasome silencer. Pharmacol Res. 2020;159:104921. doi:10.1016/j.phrs.2020.104921

16. Olcum M, Tastan B, Ercan I, Eltutan IB, Genc S. Inhibitory effects of phytochemicals on NLRP3 inflammasome activation: a review. Phytomedicine. 2020;75:153238. doi:10.1016/j. phymed.2020.153238

17. Chen G, Liu S, Pan R, et al. Curcumin Attenuates gp120-Induced Microglial Inflammation by Inhibiting Autophagy via the PI3K Pathway. Cell Mol Neurobiol. 2018;38(8):1465-1477. doi:10.1007/s10571-018-0616-3

18. Chowdhury I, Banerjee S, Driss A, et al. Curcumin attenuates proangiogenic and proinflammatory factors in human eutopic endometrial stromal cells through the NF-kappaB signaling pathway. J Cell Physiol. 2019;234(5):6298-6312. doi:10.1002/ jcp. 27360

19. Meng Z, Yan C, Deng Q, Gao DF, Niu XL. Curcumin inhibits LPS-induced inflammation in rat vascular smooth muscle cells in vitro via ROS-relative TLR4-MAPK/NF-kappaB pathways. Acta Pharmacol Sin. 2013;34(7):901-911. doi:10.1038/aps.2013.24

20. Sadeghi A, Rostamirad A, Seyyedebrahimi S, Meshkani R. Curcumin ameliorates palmitate-induced inflammation in skeletal muscle cells by regulating JNK/NF-kB pathway and ROS production. Inflammopharmacology. 2018;26(5):1265-1272. doi:10.1007/s10787-018-0466-0

21. Zeng Z, Zhan L, Liao H, Chen L, Lv X. Curcumin improves TNBS-induced colitis in rats by inhibiting IL-27 expression via the TLR4/NF-kappaB signaling pathway. Planta Med. 2013;79 (2): $102-109$.

22. Fu Y, Gao R, Cao Y, et al. Curcumin attenuates inflammatory responses by suppressing TLR4-mediated NF-kappaB signaling pathway in lipopolysaccharide-induced mastitis in mice. Int Immunopharmacol. 2014;20(1):54-58. doi:10.1016/j. intimp.2014.01.024

23. Panahi Y, Hosseini MS, Khalili N, et al. Effects of curcumin on serum cytokine concentrations in subjects with metabolic syndrome: a post-hoc analysis of a randomized controlled trial. Biomed Pharmacother. 2016;82:578-582. doi:10.1016/j. biopha.2016.05.037

24. Alizadeh F, Javadi M, Karami AA, Gholaminejad F, Kavianpour M, Haghighian HK. Curcumin nanomicelle improves semen parameters, oxidative stress, inflammatory biomarkers, and reproductive hormones in infertile men: a randomized clinical trial. Phytother Res. 2018;32(3):514-521. doi:10.1002/ptr.5998 
25. Atabaki M, Shariati-Sarabi Z, Tavakkol-Afshari J, Mohammadi M. Significant immunomodulatory properties of curcumin in patients with osteoarthritis; a successful clinical trial in Iran. Int Immunopharmacol. 2020;85:106607. doi:10.1016/j. intimp.2020.106607

26. Rahimi K, Ahmadi A, Hassanzadeh K, et al. Targeting the balance of $\mathrm{T}$ helper cell responses by curcumin in inflammatory and autoimmune states. Autoimmun Rev. 2019;18(7):738-748. doi:10.1016/j.autrev.2019.05.012

27. Momtazi-Borojeni AA, Haftcheshmeh SM, Esmaeili SA, Johnston TP, Abdollahi E, Sahebkar A. Curcumin: a natural modulator of immune cells in systemic lupus erythematosus. Autoimmun Rev. 2018;17(2):125-135. doi:10.1016/j. autrev.2017.11.016

28. Zhang W, Liu X, Zhu Y, et al. Transcriptional and posttranslational regulation of Th17/Treg balance in health and disease. Eur J Immunol. 2021. doi:10.1002/eji.202048794

29. Chang Y, Zhai L, Peng J, Wu H, Bian Z, Xiao H. Phytochemicals as regulators of Th17/Treg balance in inflammatory bowel diseases. Biomed Pharmacother. 2021;141:111931. doi:10.1016/ j.biopha.2021.111931

30. Wei C, Wang JY, Xiong F, et al. Curcumin ameliorates DSSinduced colitis in mice by regulating the Treg/Th17 signaling pathway. Mol Med Rep. 2021;23(1):254.

31. Derochette S, Franck T, Mouithys-Mickalad A, et al. Curcumin and resveratrol act by different ways on NADPH oxidase activity and reactive oxygen species produced by equine neutrophils. Chem Biol Interact. 2013;206(2):186-193. doi:10.1016/j. cbi.2013.09.011

32. Lin X, Bai D, Wei Z, et al. Curcumin attenuates oxidative stress in RAW264.7 cells by increasing the activity of antioxidant enzymes and activating the Nrf2-Keap1 pathway. PLoS One. 2019;14(5):e0216711. doi:10.1371/journal.pone.0216711

33. Yousefian M, Shakour N, Hosseinzadeh H, Hayes AW, Hadizadeh F, Karimi G. The natural phenolic compounds as modulators of NADPH oxidases in hypertension. Phytomedicine. 2019;55:200-213. doi:10.1016/j.phymed.2018.08.002

34. Kaplan GG. The global burden of IBD: from 2015 to 2025. Nat Rev Gastroenterol Hepatol. 2015;12(12):720-727. doi:10.1038/ nrgastro.2015.150

35. Gong Z, Zhao S, Zhou J, et al. Curcumin alleviates DSS-induced colitis via inhibiting NLRP3 inflammsome activation and IL-1beta production. Mol Immunol. 2018;104:11-19. doi:10.1016/j.molimm.2018.09.004

36. Burge K, Gunasekaran A, Eckert J, Chaaban H. Curcumin and intestinal inflammatory diseases: molecular mechanisms of protection. Int J Mol Sci. 2019;20(8). doi:10.3390/ijms20081912

37. Wang Y, Tang Q, Duan P, Yang L. Curcumin as a therapeutic agent for blocking NF-kappaB activation in ulcerative colitis. Immunopharmacol Immunotoxicol. 2018;40(6):476-482. doi:10.1080/08923973.2018.1469145

38. Fallahi F, Borran S, Ashrafizadeh M, et al. Curcumin and inflammatory bowel diseases: from in vitro studies to clinical trials. $\mathrm{Mol}$ Immunol. 2021;130:20-30. doi:10.1016/j.molimm.2020.11.016

39. Sadeghi N, Mansoori A, Shayesteh A, Hashemi SJ. The effect of curcumin supplementation on clinical outcomes and inflammatory markers in patients with ulcerative colitis. Phytother Res. 2020;34 (5):1123-1133. doi:10.1002/ptr.6581

40. Sugimoto K, Ikeya K, Bamba S, et al. Highly bioavailable curcumin derivative ameliorates Crohn's disease symptoms: a randomized, double-blind, multicenter study. J Crohns Colitis. 2020;14(12):1693-1701. doi:10.1093/ecco-jcc/jjaa097

41. Samoila I, Dinescu S, Costache M. Interplay between Cellular and Molecular Mechanisms Underlying Inflammatory Bowel Diseases Development-A Focus on Ulcerative Colitis. Cells. 2020;9(7):1647. doi:10.3390/cells9071647
42. Larabi A, Barnich N, Nguyen HTT. New insights into the interplay between autophagy, gut microbiota and inflammatory responses in IBD. Autophagy. 2020;16(1):38-51. doi:10.1080/ 15548627.2019.1635384

43. Shao BZ, Yao Y, Zhai JS, Zhu JH, Li JP, Wu K. The role of autophagy in inflammatory bowel disease. Front Physiol. 2021;12:621132. doi:10.3389/fphys.2021.621132

44. Zhang L, Xue H, Zhao G, et al. Curcumin and resveratrol suppress dextran sulfate sodiuminduced colitis in mice. Mol Med Rep. 2019;19(4):3053-3060.

45. Yue W, Liu Y, Li X, Lv L, Huang J, Liu J. Curcumin ameliorates dextran sulfate sodium-induced colitis in mice via regulation of autophagy and intestinal immunity. Turk J Gastroenterol. 2019;30 (3):290-298. doi:10.5152/tjg.2019.18342

46. Cunha Neto F, Marton LT, de Marqui SV, Lima TA, Barbalho SM. Curcuminoids from Curcuma Longa: new adjuvants for the treatment of crohn's disease and ulcerative colitis? Crit Rev Food Sci Nutr. 2019;59(13):2136-2143. doi:10.1080/ 10408398.2018.1456403

47. Grammatikopoulou MG, Gkiouras K, Theodoridis X, Asteriou E, Forbes A, Bogdanos DP. Oral Adjuvant Curcumin Therapy for Attaining Clinical Remission in Ulcerative Colitis: a Systematic Review and Meta-Analysis of Randomized Controlled Trials. Nutrients. 2018;10(11):1737. doi:10.3390/nu10111737

48. Zheng T, Wang X, Chen Z, He A, Zheng Z, Liu G. Efficacy of adjuvant curcumin therapy in ulcerative colitis: a meta-analysis of randomized controlled trials. J Gastroenterol Hepatol. 2020;35 (5):722-729. doi:10.1111/jgh.14911

49. Coelho MR, Romi MD, Ferreira D, Zaltman C, Soares-Mota M. The use of curcumin as a complementary therapy in ulcerative colitis: a systematic review of randomized controlled clinical trials. Nutrients. 2020;12(8):2296. doi:10.3390/nu12082296

50. Kumar S, Ahuja V, Sankar MJ, Kumar A, Moss AC. Curcumin for maintenance of remission in ulcerative colitis. Cochrane Database Syst Rev. 2012;10:CD008424.

51. Ng QX, Soh AYS, Loke W, Venkatanarayanan N, Lim DY, Yeo WS. A Meta-Analysis of the Clinical Use of Curcumin for Irritable Bowel Syndrome (IBS). J Clin Med. 2018;7(10):298. doi: $10.3390 / \mathrm{jcm} 7100298$

52. Alt F, Chong PW, Teng E, Uebelhack R. Evaluation of Benefit and Tolerability of IQP-CL-101 (Xanthofen) in the Symptomatic Improvement of Irritable Bowel Syndrome: a Double-Blinded, Randomised, Placebo-Controlled Clinical Trial. Phytother Res. 2017;31(7):1056-1062. doi:10.1002/ptr.5826

53. Portincasa P, Bonfrate L, Scribano ML, et al. Curcumin and Fennel Essential Oil Improve Symptoms and Quality of Life in Patients with Irritable Bowel Syndrome. $J$ Gastrointestin Liver Dis. 2016;25(2):151-157. doi:10.15403/jgld.2014.1121.252.ccm

54. Bijlsma JWJ, Berenbaum F, Lafeber FPJG. Osteoarthritis: an update with relevance for clinical practice. Lancet. 2011;377 (9783):2115-2126. doi:10.1016/S0140-6736(11)60243-2

55. Glyn-Jones S, Palmer AJR, Agricola R, et al. Osteoarthritis. Lancet. 2015;386(9991):376-387. doi:10.1016/S0140-6736(14) 60802-3

56. Seo EJ, Efferth T, Panossian A. Curcumin downregulates expression of opioid-related nociceptin receptor gene (OPRL1) in isolated neuroglia cells. Phytomedicine. 2018;50:285-299. doi:10.1016/j.phymed.2018.09.202

57. Zhang Z, Leong DJ, Xu L, et al. Curcumin slows osteoarthritis progression and relieves osteoarthritis-associated pain symptoms in a post-traumatic osteoarthritis mouse model. Arthritis Res Ther. 2016;18(1):128. doi:10.1186/s13075-016-1025-y

58. Kang C, Jung E, Hyeon H, Seon S, Lee D. Acid-activatable polymeric curcumin nanoparticles as therapeutic agents for osteoarthritis. Nanomedicine. 2020;23:102104. doi:10.1016/j. nano.2019.102104 
59. Wang Q, Ye C, Sun S, et al. Curcumin attenuates collagen-induced rat arthritis via anti-inflammatory and apoptotic effects. Int Immunopharmacol. 2019;72:292-300. doi:10.1016/j. intimp.2019.04.027

60. Wang J, Wang X, Cao Y, Huang T, Song DX, Tao HR. Therapeutic potential of hyaluronic acid/chitosan nanoparticles for the delivery of curcuminoid in knee osteoarthritis and an in vitro evaluation in chondrocytes. Int J Mol Med. 2018;42(5):2604-2614.

61. Yan D, He B, Guo J, Li S, Wang J. Involvement of TLR4 in the protective effect of intra-articular administration of curcumin on rat experimental osteoarthritis. Acta Cir Bras. 2019;34(6): e201900604. doi:10.1590/s0102-865020190060000004

62. Lepetsos P, Papavassiliou KA, Papavassiliou AG. Redox and NF-kappaB signaling in osteoarthritis. Free Radic Biol Med. 2019;132:90-100. doi:10.1016/j.freeradbiomed.2018.09.025

63. Park S, Lee LR, Seo JH, Kang S. Curcumin and tetrahydrocurcumin both prevent osteoarthritis symptoms and decrease the expressions of pro-inflammatory cytokines in estrogen-deficient rats. Genes Nutr. 2016;11:2. doi:10.1186/s12263-016-0520-4

64. Mollazadeh H, Cicero AFG, Blesso CN, Pirro M, Majeed M, Sahebkar A. Immune modulation by curcumin: the role of interleukin-10. Crit Rev Food Sci Nutr. 2019;59(1):89-101. doi:10.1080/10408398.2017.1358139

65. Panaro MA, Corrado A, Benameur T, Paolo CF, Cici D, Porro C. The Emerging Role of Curcumin in the Modulation of TLR-4 Signaling Pathway: focus on Neuroprotective and Anti-Rheumatic Properties. Int J Mol Sci. 2020;21(7):2299. doi:10.3390/ijms21072299

66. Zhang N, Liu Z, Luo H, et al. FM0807 decelerates experimental arthritis progression by inhibiting inflammatory responses and joint destruction via modulating NF-kappaB and MAPK pathways. Biosci Rep. 2019;39(9). doi:10.1042/BSR20182263.

67. Yan F, Li H, Zhong Z, et al. Co-Delivery of Prednisolone and Curcumin in Human Serum Albumin Nanoparticles for Effective Treatment of Rheumatoid Arthritis. Int $J$ Nanomedicine. 2019;14:9113-9125. doi:10.2147/IJN.S219413

68. Manca ML, Lattuada D, Valenti D, et al. Potential therapeutic effect of curcumin loaded hyalurosomes against inflammatory and oxidative processes involved in the pathogenesis of rheumatoid arthritis: the use of fibroblast-like synovial cells cultured in synovial fluid. Eur J Pharm Biopharm. 2019;136:84-92. doi:10.1016/ j.ejpb.2019.01.012

69. Chen B, Li H, Ou G, Ren L, Yang X, Zeng M. Curcumin attenuates MSU crystal-induced inflammation by inhibiting the degradation of IkappaBalpha and blocking mitochondrial damage. Arthritis Res Ther. 2019;21(1):193. doi:10.1186/s13075-019-1974-Z

70. Li X, Xu DQ, Sun DY, Zhang T, He X, Xiao DM. Curcumin ameliorates monosodium urate-induced gouty arthritis through Nod-like receptor 3 inflammasome mediation via inhibiting nuclear factor-kappa B signaling. J Cell Biochem. 2019;120 (4):6718-6728. doi:10.1002/jcb.27969

71. Srivastava S, Saksena AK, Khattri S, Kumar S, Dagur RS Curcuma longa extract reduces inflammatory and oxidative stress biomarkers in osteoarthritis of knee: a four-month, double-blind, randomized, placebo-controlled trial. Inflammopharmacology. 2016;24(6):377-388. doi:10.1007/s10787-016-0289-9

72. Wang Z, Jones G, Winzenberg T, et al. Effectiveness of curcuma longa extract for the treatment of symptoms and effusion-synovitis of knee osteoarthritis: a randomized trial. Ann Intern Med. 2020;173(11):861-869. doi:10.7326/M20-0990

73. Heidari-Beni M, Moravejolahkami AR, Gorgian P, Askari G, Tarrahi MJ, Bahreini-Esfahani N. Herbal formulation "turmeric extract, black pepper, and ginger" versus Naproxen for chronic knee osteoarthritis: a randomized, double-blind, controlled clinical trial. Phytother Res. 2020;34(8):2067-2073. doi:10.1002/ ptr.6671
74. Chandran B, Goel A. A randomized, pilot study to assess the efficacy and safety of curcumin in patients with active rheumatoid arthritis. Phytother Res. 2012;26(11):1719-1725. doi:10.1002/ ptr.4639

75. Krueger JG, Brunner PM. Interleukin-17 alters the biology of many cell types involved in the genesis of psoriasis, systemic inflammation and associated comorbidities. Exp Dermatol. 2018;27(2):115-123. doi:10.1111/exd.13467

76. Glitzner E, Korosec A, Brunner PM, et al. Specific roles for dendritic cell subsets during initiation and progression of psoriasis. EMBO Mol Med. 2014;6(10):1312-1327. doi:10.15252/emmm.201404114

77. Armstrong AW, Read C. Pathophysiology, Clinical Presentation, and Treatment of Psoriasis: a Review. JAMA. 2020;323 (19):1945-1960. doi:10.1001/jama.2020.4006

78. Skyvalidas D, Mavropoulos A, Tsiogkas S, et al. Curcumin mediates attenuation of pro-inflammatory interferon gamma and interleukin 17 cytokine responses in psoriatic disease, strengthening its role as a dietary immunosuppressant. Nutr Res. 2020;75:95-108. doi:10.1016/j.nutres.2020.01.005

79. Campbell NK, Fitzgerald HK, Malara A, et al. Naturally derived Heme-Oxygenase 1 inducers attenuate inflammatory responses in human dendritic cells and $\mathrm{T}$ cells: relevance for psoriasis treatment. Sci Rep. 2018;8(1):10287. doi:10.1038/s41598-01828488-6

80. Varma SR, Sivaprakasam TO, Mishra A, Prabhu S. M R, P R. Imiquimod-induced psoriasis-like inflammation in differentiated Human keratinocytes: its evaluation using curcumin. Eur J Pharmacol. 2017;813:33-41.

81. Xia YP, Li B, Hylton D, Detmar M, Yancopoulos GD, Rudge JS. Transgenic delivery of VEGF to mouse skin leads to an inflammatory condition resembling human psoriasis. Blood. 2003;102 (1):161-168. doi:10.1182/blood-2002-12-3793

82. Kang D, Li B, Luo L, et al. Curcumin shows excellent therapeutic effect on psoriasis in mouse model. Biochimie. 2016;123:73-80.

83. Sun J, Zhao Y, Jin H, Hu J. Curcumin relieves TPA-induced Th1 inflammation in $\mathrm{K} 14-\mathrm{VEGF}$ transgenic mice. Int Immunopharmacol. 2015;25(2):235-241. doi:10.1016/j. intimp.2015.02.007

84. Filippone A, Consoli GML, Granata G, et al. Topical Delivery of Curcumin by Choline-Calix[4]arene-Based Nanohydrogel Improves Its Therapeutic Effect on a Psoriasis Mouse Model. Int J Mol Sci. 2020;21(14):5053. doi:10.3390/ijms21145053

85. Zhang Y, Xia Q, Li Y, et al. CD44 Assists the Topical Anti-Psoriatic Efficacy of Curcumin-Loaded Hyaluronan-Modified Ethosomes: a New Strategy for Clustering Drug in Inflammatory Skin. Theranostics. 2019;9(1):48-64. doi: $10.7150 /$ thno. 29715

86. Antiga E, Bonciolini V, Volpi W, Del Bianco E, Caproni M. Oral Curcumin (Meriva) Is Effective as an Adjuvant Treatment and Is Able to Reduce IL-22 Serum Levels in Patients with Psoriasis Vulgaris. Biomed Res Int. 2015;2015:283634. doi:10.1155/2015/ 283634

87. Carrion-Gutierrez M, Ramirez-Bosca A, Navarro-Lopez V, et al. Effects of Curcuma extract and visible light on adults with plaque psoriasis. Eur J Dermatol. 2015;25(3):240-246. doi:10.1684/ ejd.2015.2584

88. Bilia AR, Bergonzi MC, Isacchi B, Antiga E, Caproni M. Curcumin nanoparticles potentiate therapeutic effectiveness of acitrein in moderate-to-severe psoriasis patients and control serum cholesterol levels. J Pharm Pharmacol. 2018;70 (7):919-928. doi:10.1111/jphp.12910

89. Kurd SK, Smith N, VanVoorhees A, et al. Oral curcumin in the treatment of moderate to severe psoriasis vulgaris: a prospective clinical trial. J Am Acad Dermatol. 2008;58(4):625-631. doi:10.1016/j.jaad.2007.12.035 
90. Mohammadi A, Blesso CN, Barreto GE, Banach M, Majeed M, Sahebkar A. Macrophage plasticity, polarization and function in response to curcumin, a diet-derived polyphenol, as an immunomodulatory agent. $J$ Nutr Biochem. 2019;66:1-16. doi:10.1016/j. jnutbio.2018.12.005

91. Karrys A, Rady I, Chamcheu RN, et al. Bioactive Dietary VDR Ligands Regulate Genes Encoding Biomarkers of Skin Repair That Are Associated with Risk for Psoriasis. Nutrients. 2018;10 (2):174. doi:10.3390/nu10020174

92. Gupta R, Ahn R, Lai K, et al. Landscape of Long Noncoding RNAs in Psoriatic and Healthy Skin. J Invest Dermatol. 2016;136 (3):603-609. doi:10.1016/j.jid.2015.12.009

93. Miller AH, Maletic V, Raison CL. Inflammation and its discontents: the role of cytokines in the pathophysiology of major depression. Biol Psychiatry. 2009;65(9):732-741. doi:10.1016/j. biopsych.2008.11.029

94. Miller AH, Raison CL. The role of inflammation in depression: from evolutionary imperative to modern treatment target. Nat Rev Immunol. 2016;16(1):22-34. doi:10.1038/nri.2015.5

95. Raison CL, Capuron L, Miller AH. Cytokines sing the blues: inflammation and the pathogenesis of depression. Trends Immunol. 2006;27(1):24-31. doi:10.1016/j.it.2005.11.006

96. Dowlati Y, Herrmann N, Swardfager W, et al. A meta-analysis of cytokines in major depression. Biol Psychiatry. 2010;67 (5):446-457. doi:10.1016/j.biopsych.2009.09.033

97. Maes M, Song C, Yirmiya R. Targeting IL-1 in depression. Exp Opinion Therapeutic Targets. 2012;16(11):1097-1112.

98. Kohler-Forsberg O, Hjorthoj CNL. C, Nordentoft M, Mors O, Benros ME. Efficacy of anti-inflammatory treatment on major depressive disorder or depressive symptoms: meta-analysis of clinical trials. Acta Psychiatr Scand. 2019;139(5):404-419. doi:10.1111/acps.13016

99. Kohler O, Benros ME, Nordentoft $M$, et al. Effect of anti-inflammatory treatment on depression, depressive symptoms, and adverse effects: a systematic review and meta-analysis of randomized clinical trials. JAMA Psychiatry. 2014;71 (12):1381-1391. doi:10.1001/jamapsychiatry.2014.1611

100. Kappelmann N, Lewis G, Dantzer R, Jones PB, Khandaker GM. Antidepressant activity of anti-cytokine treatment: a systematic review and meta-analysis of clinical trials of chronic inflammatory conditions. Mol Psychiatry. 2018;23(2):335-343. doi:10.1038/mp.2016.167

101. Ng QX, Koh SSH, Chan HW, Ho CYX. Clinical Use of Curcumin in Depression: a Meta-Analysis. J Am Med Dir Assoc. 2017;18(6):503-508.

102. Zhang WY, Guo YJ, Han WX, et al. Curcumin relieves depressive-like behaviors via inhibition of the NLRP3 inflammasome and kynurenine pathway in rats suffering from chronic unpredictable mild stress. Int Immunopharmacol. 2019;67:138-144. doi:10.1016/j.intimp.2018.12.012

103. Vasileva LV, Saracheva KE, Ivanovska MV, et al. Antidepressant-like effect of salidroside and curcumin on the immunoreactivity of rats subjected to a chronic mild stress model. Food Chem Toxicol. 2018;121:604-611. doi:10.1016/j. fct.2018.09.065

104. Fan C, Song Q, Wang P, Li Y, Yang M, Yu SY. Neuroprotective Effects of Curcumin on IL-1beta-Induced Neuronal Apoptosis and Depression-Like Behaviors Caused by Chronic Stress in Rats. Front Cell Neurosci. 2018;12:516. doi:10.3389/ fncel.2018.00516

105. Fan C, Song Q, Wang P, et al. Curcumin Protects Against Chronic Stress-induced Dysregulation of Neuroplasticity and Depression-like Behaviors via Suppressing IL-1beta Pathway in Rats. Neuroscience. 2018;392:92-106. doi:10.1016/j. neuroscience.2018.09.028
106. Qi XJ, Liu XY, Tang LM, Li PF, Qiu F, Yang AH. Antidepressant effect of curcumin-loaded guanidine-chitosan thermo-sensitive hydrogel by nasal delivery. Pharm Dev Technol. 2020;25(3):316-325. doi:10.1080/10837450.20 19.1686524

107. Madiha S, Haider S. Curcumin restores rotenone induced depressive-like symptoms in animal model of neurotoxicity: assessment by social interaction test and sucrose preference test. Metab Brain Dis. 2019;34(1):297-308. doi:10.1007/s11011-0180352-x

108. Kaufmann FN, Gazal M, Bastos CR, Kaster MP, Ghisleni G. Curcumin in depressive disorders: an overview of potential mechanisms, preclinical and clinical findings. Eur J Pharmacol. 2016;784:192-198. doi:10.1016/j.ejphar.2016.05.026

109. Abd-Rabo MM, Georgy GS, Saied NM, Hassan WA. Involvement of the serotonergic system and neuroplasticity in the antidepressant effect of curcumin in ovariectomized rats: comparison with oestradiol and fluoxetine. Phytother Res. 2019;33(2):387-396. doi:10.1002/ptr.6232

110. Fusar-Poli L, Vozza L, Gabbiadini A, et al. Curcumin for depression: a meta-analysis. Crit Rev Food Sci Nutr. 2020;60 (15):2643-2653. doi:10.1080/10408398.2019.1653260

111. Dome P, Tombor L, Lazary J, Gonda X, Rihmer Z. Natural health products, dietary minerals and over-the-counter medications as add-on therapies to antidepressants in the treatment of major depressive disorder: a review. Brain Res Bull. 2019;146:51-78.

112. Ramaholimihaso T, Bouazzaoui F, Kaladjian A. Curcumin in Depression: potential Mechanisms of Action and Current Evidence-A Narrative Review. Front Psychiatry. 2020;11:572533. doi:10.3389/fpsyt.2020.572533

113. Kanchanatawan B, Tangwongchai S, Sughondhabhirom A, et al. Add-on Treatment with Curcumin Has Antidepressive Effects in Thai Patients with Major Depression: results of a Randomized Double-Blind Placebo-Controlled Study. Neurotox Res. 2018;33 (3):621-633. doi:10.1007/s12640-017-9860-4

114. Andrade C. A critical examination of studies on curcumin for depression. $J$ Clin Psychiatry. 2014;75(10):e1110-1112. doi:10.4088/JCP.14f09489

115. den Dekker WK, Cheng C, Pasterkamp G, Duckers HJ. Toll like receptor 4 in atherosclerosis and plaque destabilization. Atherosclerosis. 2010;209(2):314-320. doi:10.1016/j. atherosclerosis.2009.09.075

116. Paramel Varghese G, Folkersen L, Strawbridge RJ, et al. NLRP3 Inflammasome Expression and Activation in Human Atherosclerosis. J Am Heart Assoc. 2016;5:5. doi:10.1161/ JAHA.115.003031

117. Winkels $H$, Ehinger $\mathrm{E}$, Vassallo $\mathrm{M}$, et al. Atlas of the Immune Cell Repertoire in Mouse Atherosclerosis Defined by Single-Cell RNA-Sequencing and Mass Cytometry. Circ Res. 2018;122 (12):1675-1688. doi:10.1161/CIRCRESAHA.117.312513

118. Hansson GK, Robertson AK, Soderberg-Naucler C. Inflammation and atherosclerosis. Annu Rev Pathol. 2006;1:297-329. doi:10.1146/annurev.pathol.1.110304.100100

119. Bäck M, Yurdagul A, Tabas I, Öörni K, Kovanen PT. Inflammation and its resolution in atherosclerosis: mediators and therapeutic opportunities. Nat Rev Cardiol. 2019. doi:10.1038/ s41569-019-0169-2

120. Gao S, Zhang W, Zhao Q, et al. Curcumin ameliorates atherosclerosis in apolipoprotein $\mathrm{E}$ deficient asthmatic mice by regulating the balance of Th2/Treg cells. Phytomedicine. 2019;52:129-135. doi:10.1016/j.phymed.2018.09.194

121. Momtazi-Borojeni AA, Abdollahi E, Nikfar B, Chaichian S, Ekhlasi-Hundrieser M. Curcumin as a potential modulator of M1 and M2 macrophages: new insights in atherosclerosis therapy. Heart Fail Rev. 2019;24(3):399-409. doi:10.1007/ s10741-018-09764-z 
122. Zhang S, Zou J, Li P, Zheng X, Feng D. Curcumin Protects against Atherosclerosis in Apolipoprotein E-Knockout Mice by Inhibiting Toll-like Receptor 4 Expression. J Agric Food Chem. 2018;66(2):449-456. doi:10.1021/acs.jafc.7b04260

123. van der Heijden $T$, Kritikou E, Venema W, et al. NLRP3 Inflammasome Inhibition by MCC950 Reduces Atherosclerotic Lesion Development in Apolipoprotein E-Deficient Mice-Brief Report. Arterioscler Thromb Vasc Biol. 2017;37(8):1457-1461. doi:10.1161/ATVBAHA.117.309575

124. Ridker PM, Everett BM, Thuren T, et al. Antiinflammatory Therapy with Canakinumab for Atherosclerotic Disease. $N$ Engl J Med. 2017;377(12):1119-1131. doi:10.1056/NEJMoa1707914

125. Han Y, Sun HJ, Tong Y, et al. Curcumin attenuates migration of vascular smooth muscle cells via inhibiting NFkappaB-mediated NLRP3 expression in spontaneously hypertensive rats. $J$ Nutr Biochem. 2019;72:108212. doi:10.1016/j.jnutbio.2019.07.003

126. Li X, Xiao H, Lin C, et al. Synergistic effects of liposomes encapsulating atorvastatin calcium and curcumin and targeting dysfunctional endothelial cells in reducing atherosclerosis. Int J Nanomedicine. 2019;14:649-665. doi:10.2147/IJN.S189819

127. Lin K, Chen H, Chen X, Qian J, Huang S, Huang W. Efficacy of Curcumin on Aortic Atherosclerosis: a Systematic Review and Meta-Analysis in Mouse Studies and Insights into Possible Mechanisms. Oxid Med Cell Longev. 2020;2020:1520747. doi: $10.1155 / 2020 / 1520747$

128. Simental-Mendia LE, Pirro M, Gotto AM, et al. Lipid-modifying activity of curcuminoids: a systematic review and meta-analysis of randomized controlled trials. Crit Rev Food Sci Nutr. 2019;59 (7):1178-1187. doi:10.1080/10408398.2017.1396201

129. Sahebkar A. A systematic review and meta-analysis of randomized controlled trials investigating the effects of curcumin on blood lipid levels. Clin Nutr. 2014;33(3):406-414. doi:10.1016/j clnu.2013.09.012

130. Worldometer. 2021. Available from: https://wwwworldometer sinfo/coronavirus/.Accessed August 12, 2021.

131. Guan WJ, Ni ZY, Hu Y, et al. Clinical Characteristics of Coronavirus Disease 2019 in China. N Engl J Med. 2020;382 (18):1708-1720. doi:10.1056/NEJMoa2002032

132. Huang C, Wang Y, Li X, et al. Clinical features of patients infected with 2019 novel coronavirus in Wuhan, China. Lancet 2020;395(10223):497-506. doi:10.1016/S0140-6736(20)30183-5

133. Liu J, Li S, Liu J, et al. Longitudinal characteristics of lymphocyte responses and cytokine profiles in the peripheral blood of SARS-CoV-2 infected patients. EBioMedicine. 2020;55:102763. doi:10.1016/j.ebiom.2020.102763

134. Xiong Y, Liu Y, Cao L, et al. Transcriptomic characteristics of bronchoalveolar lavage fluid and peripheral blood mononuclear cells in COVID-19 patients. Emerg Microbes Infect. 2020;9 (1):761-770. doi:10.1080/22221751.2020.1747363

135. Rattis BAC, Ramos SG, Celes MRN. Curcumin as a Potential Treatment for COVID-19. Front Pharmacol. 2021;12:675287. doi:10.3389/fphar.2021.675287

136. Valizadeh H, Abdolmohammadi-Vahid S, Danshina S, et al. Nano-curcumin therapy, a promising method in modulating inflammatory cytokines in COVID-19 patients. Int Immunopharmacol. 2020;89(Pt B):107088. doi:10.1016/j. intimp.2020.107088

137. Tahmasebi S, El-Esawi MA, Mahmoud $\mathrm{ZH}$, et al. Immunomodulatory effects of nanocurcumin on Th17 cell responses in mild and severe COVID-19 patients. J Cell Physiol. 2021;236(7):5325-5338. doi:10.1002/jcp.30233

138. Tahmasebi S, Saeed BQ, Temirgalieva E, et al. Nanocurcumin improves Treg cell responses in patients with mild and severe SARS-CoV2. Life Sci. 2021;276:119437. doi:10.1016/j. lfs.2021.119437
139. Saber-Moghaddam N, Salari S, Hejazi S, et al. Oral nano-curcumin formulation efficacy in management of mild to moderate hospitalized coronavirus disease-19 patients: an open label nonrandomized clinical trial. Phytother Res. 2021;35 (5):2616-2623. doi:10.1002/ptr.7004

140. Pawar KS, Mastud RN, Pawar SK, et al. Oral Curcumin With Piperine as Adjuvant Therapy for the Treatment of COVID-19: a Randomized Clinical Trial. Front Pharmacol. 2021;12:669362. doi:10.3389/fphar.2021.669362

141. Cuomo J, Appendino G, Dern AS, et al. Comparative absorption of a standardized curcuminoid mixture and its lecithin formulation. J Nat Prod. 2011;74(4):664-669. doi:10.1021/ np1007262

142. Tsuda T. Curcumin as a functional food-derived factor: degradation products, metabolites, bioactivity, and future perspectives. Food Funct. 2018;9(2):705-714. doi:10.1039/C7FO01242J

143. Schneider C, Gordon ON, Edwards RL, Luis PB. Degradation of Curcumin: from Mechanism to Biological Implications. J Agric Food Chem. 2015;63(35):7606-7614. doi:10.1021/acs.jafc.5b00244

144. Chen Y, Lu Y, Lee RJ, Xiang G. Nano Encapsulated Curcumin: and Its Potential for Biomedical Applications. Int $J$ Nanomedicine. 2020;15:3099-3120. doi:10.2147/IJN.S210320

145. Ipar VS, Dsouza A, Devarajan PV. Enhancing Curcumin Oral Bioavailability Through Nanoformulations. Eur J Drug Metab Pharmacokinet. 2019;44(4):459-480. doi:10.1007/s13318-01900545-z

146. Ma Z, Wang N, He H, Tang X. Pharmaceutical strategies of improving oral systemic bioavailability of curcumin for clinical application. J Control Release. 2019;316:359-380. doi:10.1016/j. jconrel.2019.10.053

147. Stohs SJ, Chen O, Ray SD, Ji J, Bucci LR, Preuss HG. Highly Bioavailable Forms of Curcumin and Promising Avenues for Curcumin-Based Research and Application: a Review. Molecules. 2020;25(6):1397. doi:10.3390/molecules25061397

148. Chainoglou E, Hadjipavlou-Litina D. Curcumin analogues and derivatives with anti-proliferative and anti-inflammatory activity: structural characteristics and molecular targets. Expert Opin Drug Discov. 2019;14(8):821-842. doi:10.1080/17460441.2019.1614560

149. Szebeni GJ, Nagy LI, Berko A, et al. The Anti-Inflammatory Role of Mannich Curcuminoids; Special Focus on Colitis. Molecules. 2019;24(8):1546. doi:10.3390/molecules24081546

150. Coury JR, Nixon R, Collins M, Schwartz J, Chahine NO, Grande DA. Oral Administration of a Chemically Modified Curcumin, TRB-N0224, Reduced Inflammatory Cytokines and Cartilage Erosion in a Rabbit ACL Transection Injury Model. Cartilage. 2021;12(2):251-262. doi:10.1177/1947603518815263

151. Qian J, Chen X, Shu S, et al. Design and synthesis novel di-carbonyl analogs of curcumin (DACs) act as potent anti-inflammatory agents against LPS-induced acute lung injury (ALI). Eur J Med Chem. 2019;167:414-425. doi:10.1016/j. ejmech.2019.02.042

152. Noureddin SA, El-Shishtawy RM, Al-Footy KO. Curcumin analogues and their hybrid molecules as multifunctional drugs. Eur J Med Chem. 2019;182:111631. doi:10.1016/j.ejmech.2019.111631

153. Cheng F, Chen Y, Zhan Z, et al. Curc-mPEG454, a PEGylated Curcumin Derivative, Improves Anti-inflammatory and Antioxidant Activities: a Comparative Study. Inflammation. 2018;41(2):579-594. doi:10.1007/s10753-017-0714-2

154. Wang ZS, Chen LZ, Zhou HP, Liu XH, Chen FH. Diarylpentadienone derivatives (curcumin analogues): synthesis and anti-inflammatory activity. Bioorg Med Chem Lett. 2017;27 (8):1803-1807. doi:10.1016/j.bmcl.2017.02.056

155. Ye $\mathrm{L}, \mathrm{Hu} \mathrm{X}, \mathrm{Hu} \mathrm{X}$, et al. Curcumin analogue $\mathrm{C} 66$ attenuates obesity-induced renal injury by inhibiting chronic inflammation. Biomed Pharmacother. 2021;137:111418. doi:10.1016/j. biopha.2021.111418 
156. Hadzi-Petrushev N, Angelovski M, Rebok K, Mitrokhin V, Kamkin A, Mladenov M. Antioxidant and anti-inflammatory effects of the monocarbonyl curcumin analogs B2BRBC and C66 in monocrotaline-induced right ventricular hypertrophy. J Biochem Mol Toxicol. 2019;33(8):e22353. doi:10.1002/jbt.22353

157. Gu Y, Zhu Y, Deng G, Liu S, Sun Y, Lv W. Curcumin analogue AI-44 alleviates MSU-induced gouty arthritis in mice via inhibiting cathepsin B-mediated NLRP3 inflammasome activation. Int Immunopharmacol. 2021;93:107375. doi:10.1016/j.intimp.2021.107375

158. Wang Z, Mu W, Li P, Liu G, Yang J. Anti-inflammatory activity of ortho-trifluoromethoxy-substituted 4-piperidione-containing mono-carbonyl curcumin derivatives in vitro and in vivo. Eur J Pharm Sci. 2021;160:105756. doi:10.1016/j.ejps.2021.105756

159. Xie Z, Zhang Z, Yu S, et al. Synthesis and Evaluation of Anti-inflammatory N-Substituted 3,5-Bis(2-(trifluoromethyl)benzylidene)piperidin-4-ones. ChemMedChem. 2017;12(4):327-336. doi:10.1002/cmdc. 201600606

160. Phumsuay R, Muangnoi C, Dasuni Wasana PW, et al. Molecular Insight into the Anti-Inflammatory Effects of the Curcumin Ester Prodrug Curcumin Diglutaric Acid In Vitro and In Vivo. Int J Mol Sci. 2020;21(16):5700. doi:10.3390/ijms21165700

161. Muangnoi C, Jithavech P, Ratnatilaka Na Bhuket P. Ratnatilaka $\mathrm{Na}$ Bhuket $\mathrm{P}$, et al. A curcumin-diglutaric acid conjugated prodrug with improved water solubility and antinociceptive properties compared to curcumin. Biosci Biotechnol Biochem. 2018;82 (8):1301-1308. doi:10.1080/09168451.2018.1462694

162. Muangnoi $\mathrm{C}$, Ratnatilaka Na Bhuket $\mathrm{P}$, Jithavech $\mathrm{P}$, et al. ScaleUp Synthesis and In Vivo Anti-Tumor Activity of Curcumin Diethyl Disuccinate, an Ester Prodrug of Curcumin, in HepG2-Xenograft Mice. Pharmaceutics. 2019;11(8):373. doi:10.3390/pharmaceutics11080373

163. Muangnoi C, Sharif U. Ratnatilaka Na Bhuket P, Rojsitthisak P, Paraoan L. Protective Effects of Curcumin Ester Prodrug, Curcumin Diethyl Disuccinate against H2O2-Induced Oxidative Stress in Human Retinal Pigment Epithelial Cells: potential Therapeutic Avenues for Age-Related Macular Degeneration. Int J Mol Sci. 2019;20(13):548.

164. Limcharoen T, Muangnoi C, Dasuni Wasana PW, et al. Improved antiallodynic, antihyperalgesic and anti-inflammatory response achieved through potential prodrug of curcumin, curcumin diethyl diglutarate in a mouse model of neuropathic pain. Eur J Pharmacol. 2021;899:174008. doi:10.1016/j.ejphar.2021.174008

165. Sorasitthiyanukarn FN. Ratnatilaka Na Bhuket P, Muangnoi C, Rojsitthisak P, Rojsitthisak P. Chitosan/alginate nanoparticles as a promising carrier of novel curcumin diethyl diglutarate. Int $J$ Biol Macromol. 2019;131:1125-1136. doi:10.1016/j. ijbiomac.2019.03.120

166. Sasaki H, Sunagawa Y, Takahashi K. Innovative Preparation of Curcumin for Improved Oral Bioavailability. Biol Pharm Bull. 2011;34(5):660-665. doi:10.1248/bpb.34.660

167. Adachi S, Hamoya T, Fujii G, et al. Theracurmin inhibits intestinal polyp development in Apc-mutant mice by inhibiting inflammation-related factors. Cancer Sci. 2020;111 (4):1367-1374. doi:10.1111/cas.14329

168. Small GW, Siddarth P, Li Z, et al. Memory and Brain Amyloid and Tau Effects of a Bioavailable Form of Curcumin in Non-Demented Adults: a Double-Blind, Placebo-Controlled 18-Month Trial. Am J Geriatr Psychiatry. 2018;26(3):266-277. doi:10.1016/j.jagp.2017.10.010

169. Nakagawa Y, Mukai S, Yamada S, et al. The Efficacy and Safety of Highly-Bioavailable Curcumin for Treating Knee Osteoarthritis: a 6-Month Open-Labeled Prospective Study. Clin Med Insights Arthritis Musculoskelet Disord. 2020;13:1179544120948471. doi:10.1177/1179544120948471
170. Thomas JV, Smina TP, Khanna A, et al. Influence of a low-dose supplementation of curcumagalactomannoside complex (CurQfen) in knee osteoarthritis: a randomized, open-labeled, active-controlled clinical trial. Phytother Res. 2021;35 (3):1443-1455. doi:10.1002/ptr.6907

171. Sheethal S, Ratheesh M, Jose SP, et al. Anti-Ulcerative Effect of Curcumin-Galactomannoside Complex on Acetic Acid-Induced Experimental Model by Inhibiting Inflammation and Oxidative Stress. Inflammation. 2020;43(4):1411-1422. doi:10.1007/s10753020-01218-9

172. Belcaro G, Cesarone MR, Dugall M. Product-evaluation registry of Meriva $^{\circledR}$, a curcumin-phosphatidylcholine complex, for the complementary management of osteoarthritis. Panminerva Med. 2010;52 (2):55-62.

173. Belcaro G, Dugall M, Luzzi R. Meriva ${ }^{\circledR}+$ Glucosamine versus Condroitin+Glucosamine in patients with knee osteoarthritis: an observational study. Eur Rev Med Pharmacol Sci. 2014;18:3859-3963.

174. Yabas M, Orhan C, Er B, et al. A Next Generation Formulation of Curcumin Ameliorates Experimentally Induced Osteoarthritis in Rats via Regulation of Inflammatory Mediators. Front Immunol. 2021;12:609629. doi:10.3389/fimmu.2021.609629

175. Moballegh Nasery M, Abadi B, Poormoghadam D, et al. Curcumin Delivery Mediated by Bio-Based Nanoparticles: a Review. Molecules. 2020;25(3):689. doi:10.3390/molecules25030689

176. Huang Y, Canup BSB, Gou S, et al. Oral nanotherapeutics with enhanced mucus penetration and ROS-responsive drug release capacities for delivery of curcumin to colitis tissues. J Mater Chem B. 2021;9(6):1604-1615. doi:10.1039/D0TB02092C

177. Pontes-Quero GM, Benito-Garzon L, Perez Cano J, Aguilar MR, Vazquez-Lasa B. Amphiphilic polymeric nanoparticles encapsulating curcumin: antioxidant, anti-inflammatory and biocompatibility studies. Mater Sci Eng C Mater Biol Appl. 2021;121:111793. doi:10.1016/j.msec.2020.111793

178. Aguilera-Garrido A, Del Castillo-Santaella T, Galisteo-Gonzalez F, Jose Galvez-Ruiz M, Maldonado-Valderrama J. Investigating the role of hyaluronic acid in improving curcumin bioaccessibility from nanoemulsions. Food Chem. 2021;351:129301. doi:10.1016/ j.foodchem.2021.129301

179. Zhang S, Kang L, Hu S, et al. Carboxymethyl chitosan microspheres loaded hyaluronic acid/gelatin hydrogels for controlled drug delivery and the treatment of inflammatory bowel disease. Int J Biol Macromol. 2021;167:1598-1612. doi:10.1016/j.ijbiomac.2020.11.117

180. Zainuddin N, Ahmad I, Zulfakar MH, Kargarzadeh H, Ramli S. Cetyltrimethylammonium bromide-nanocrystalline cellulose (CTAB-NCC) based microemulsions for enhancement of topical delivery of curcumin. Carbohydr Polym. 2021;254:117401. doi:10.1016/j.carbpol.2020.117401

181. Hosseini-Zare MS, Sarhadi M, Zarei M, Thilagavathi R, Selvam C. Synergistic effects of curcumin and its analogs with other bioactive compounds: a comprehensive review. Eur J Med Chem. 2021;210:113072. doi:10.1016/j.ejmech.2020.113072

182. Efferth T, Oesch F. Anti-inflammatory and anti-cancer activities of frankincense: targets, treatments and toxicities. Semin Cancer Biol. 2020. doi:10.1016/j.semcancer.2020.01.015

183. Haroyan A, Mukuchyan V, Mkrtchyan N, et al. Efficacy and safety of curcumin and its combination with boswellic acid in osteoarthritis: a comparative, randomized, double-blind, placebo-controlled study. BMC Complement Altern Med. 2018;18(1):7. doi:10.1186/s12906-017-2062-z

184. Karlapudi V, Prasad Mungara AVV, Sengupta K, Davis BA, Raychaudhuri SP, Placebo-Controlled Double-Blind A. Study Demonstrates the Clinical Efficacy of a Novel Herbal Formulation for Relieving Joint Discomfort in Human Subjects with Osteoarthritis of Knee. J Med Food. 2018;21(5):511-520. doi:10.1089/jmf.2017.0065 


\section{Publish your work in this journal}

Drug Design, Development and Therapy is an international, peerreviewed open-access journal that spans the spectrum of drug design and development through to clinical applications. Clinical outcomes, patient safety, and programs for the development and effective, safe, and sustained use of medicines are a feature of the journal, which has also been accepted for indexing on PubMed Central. The manuscript management system is completely online and includes a very quick and fair peer-review system, which is all easy to use. Visit http://www. dovepress.com/testimonials.php to read real quotes from published authors.

Submit your manuscript here: https://www.dovepress.com/drug-design-development-and-therapy-journal 